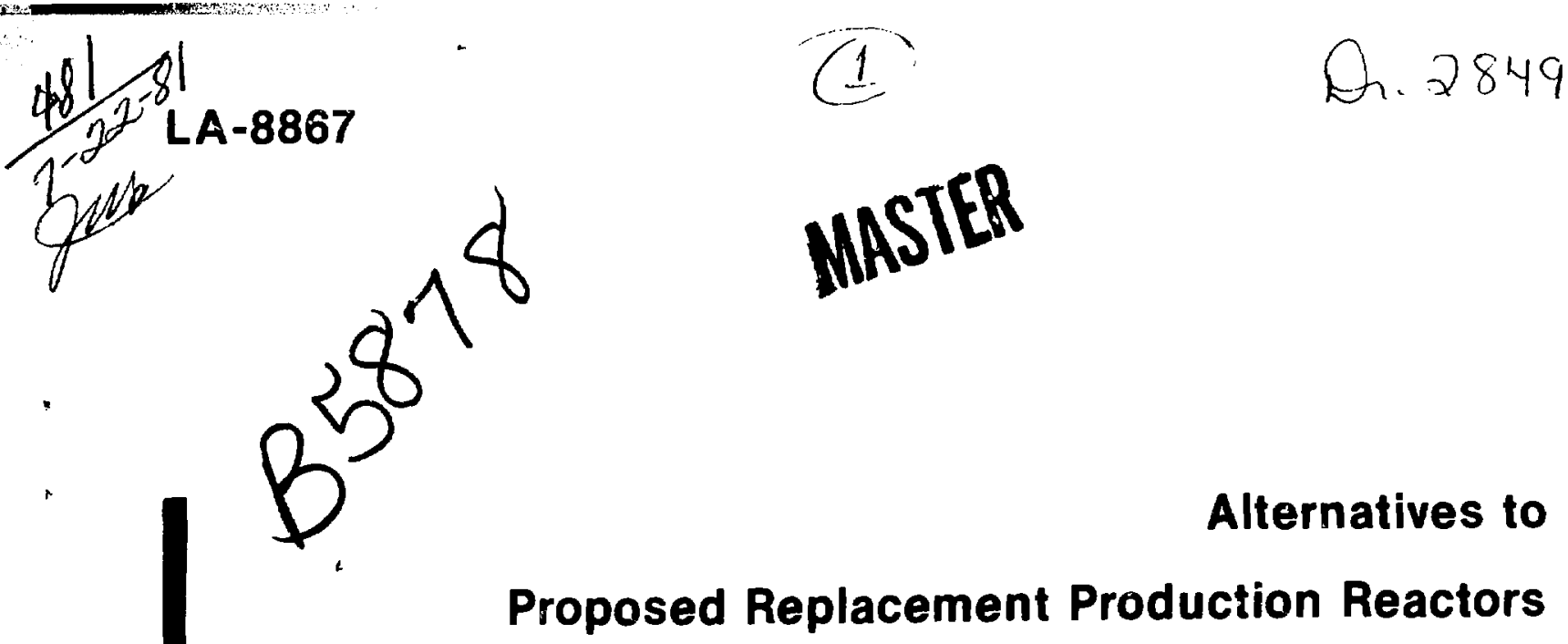

Proposed Replacement Production Reactors 
UC-78, UC-79 (Base

Technology), UC-80

Issued: June 1981

\section{Alternatives to \\ Proposed Replacement Production Reactors}

Hatice S. Cullingford 


\section{ABBREVIATIONS}

AEC Atomic Energy Commission, a former federal agency, disbanded by the Energy Reorganization Act of 1974

AIF Atomic Industrial rorum

ANL-W Argonne National Laboratory-West

$\therefore$ TR Advanced Test Reactor

BNFP Barnwell Nuclear Fuel Plant

BNL Brookhaven National Laboratory

BWR Boiling water reactor, a version of an LWR

CANDU Canadian deuterium-uranium reactor

CRBR? Clinch River Breeder Reactor Plant

d Day'

DoD Department of Defense

DOE Department of Energy

DOT Department of Transportation

EBR-II Experimental Breeder Reactor

EPA Environmental Protection Agency

ERDA Energy Research and Development Administration, a federal agency. successor to all noniegulatory functions of the Atomic Energy Commission. Merged to become DOE.

ETR Engineering Test Reactor

FFTF Fast Flux Test Facility

FY Fiscal Year

HEDL Hanford Engineering Development Laboratory

HEPA High-efficiency particulate air filters

HFBR High Flux Beam Reactor

HFIR High Flux Isotope Reactor

HLW High level wastes

HM Heavy metal

HWR Heavy-water reactor
IAEA International Atomic Energy Agency

INEL Idaho National Erigineering Laboratory

LLW Low level wastes (containing minimal transuranic elements)

LMFBR Liquid metal fast breeder reactor

LOFT Loss of Fluid Test Facility

LWBR Light-water breeder reactor

LWR Light-water reactor

$m$ Minutes

$\mathrm{MeV}$ Million electron volts

MFRP Midwest Fuel Recovery Plant

MOX Mixed oxide reactor fuel (containing both plutonium and uranium)

MW(e) Megawatts, electrical

ivW(th) Megawatts, thermal

NFS Nuclear Fuel Services

NRC Nuclear Regulatory Commission, a federal agency, successor to regulatory functions of AEC

ORNL Oak Ridge National Laboratory

ORR Oak Ridge Research Reactor

PWR Pressurized water reactor, a version of an LWR

RPR Replacement production reactor

RRY Reference reactor year. A 1000 $\mathrm{MW}(\mathrm{e})$ reactor, assumed to be operating at $80 \%$ of its maximum capacity for one year.

SGHWR Steam-Generating Heavy-Water Reactor (British)

SRP Savannah River Plant

SSCR Spectral shift control reactor

$t$ Metric ton

TRU Transuranic 


\title{
ALTERNATIVES TO PROPOSED REPLACEMENT PRODUCTION REACTORS
}

\author{
by
}

Hatice S. Sullingford

\begin{abstract}
To insure adequate supplies of plutonium and tritium for defense purposes, an independent evaluation was made by Los Alamos National Laboratory of the numerous alternatiyes to the proposed replacement production reactors (RPR). This effort concentrated on the defense fuel cycle operation and its technical implications in identifying the principal alternatives for the 1990s. The primary options were identified 2s (1) existing commercial reactors, (2) existing and planned government-owned facilities (not now used for defense materials production), and (3) other RPRs (not yet proposed) such as CANDU or CANDU-type heavy-water reactors (HWR) for both plutonium and tritium production. The evaluation considered features and differences of various options that could influence choice of RPR alternatives. Barring a change in the US approach to civilian and defense fuel cycles and precluding existing commercial reactors at government-owned sites, the most significant alternatives were identified as a CANDU-type HWR at Savannah River Plant (SRP) site or the Three Mile Island commercial reactor with reprocessing capability at Barnwell Nuclear Fuel Plant and at SRF.
\end{abstract}

\section{INTRODUCTION}

The growing disparity between production of plutonium and tritium and the demand for these materials has become a major national defense concern. Until recently, plans for nuclear weapon materials management relied upon the Savannah River Plant (SRP) for producion and chemica' processing. Earlier, the $\mathrm{N}$ Reactor and Purex Plant at the Hanford Engineering Development Laboratory (HEDL) were also in the production/processing network of the defense fuel cycle. However, as technology develops and present reactors become dated, it is vitally important to upgrade production reactors to assure availability of plutonium and tritium beyond the 1990s. The current Department of Energy (DOE) plan is to upgrante the SRP and Hanford facilities and to examine the proposals for seven types of replacement production reactors (RPR) listed in Table $\mathbf{I}$.
Los Alamos National Laboratory began this study as an independent evaluation of all possible alternatives to the proposed RPRs. The most important issues were investigated during the course of the study, including

- Fuel cycle requirements for production of plutonium and tritium

- Technology base for operability

- Power production

- Flexibility for quality, quantity, and alternate materials

- Schedule

- Location

- Resource efficiency

- Cost

- Safeguards

- Social and institutional acceptability. 
TABLE I

\section{PROPOSED RPRs}

\begin{tabular}{ll}
\hline I. LWR & Light-Water Reactor (PWR type) \\
2. HTGR & High-Temperature Gas (Cooled) Reac- \\
& tor
\end{tabular}

3. RNR Replacement N-Reactor

4. LMFBR Liquid-Metal (Cooled) Fast Breeder Reactor

5. LTHWR Low-Temperature Heavy-Water Reac-

6. HTHWR High-Temperature Heavy-Water Reactor

\section{ENB Electronuclear Breeder}

8. GCFR Gas-Cooled Fast Reactor

9. MSBR Molten Salt Breeder Rector

"Eliminated by initial screening.

After examination of available options, several possibilities were identified: (1) use of existing commercial reastors, (2) use of existing and planned governmentowned facilities that are not currently used for defense matcrial production, and (3) other RPRs, such as Canadian deuterium uranium reactors (CANDU) or CANDU-type heavy-water reactors (HWR). Appen- dices address nuclear fuel reprocessing, transportation of nuclear fuel materials, and several long-t $t \mathrm{~m}$ solutions in the form of accelerators and fusion-fission reactors. Physical science and technology are emphasized in this study, but the final choice also must take into account economic, political, social, institutional, and legal issues.

\section{THE DEFENSE FUEL CYCLE}

Figure I shows a generalized block diagram of the defense fuel cycle that produces plutonium and tritium. A nuclear production plant is the source of irradiation for the ${ }^{238} \mathrm{U}$ fuel and ${ }^{6} \mathrm{Li}$ target. A typical fission reaction occurring in a nuclear reactor is illustrated by

${ }^{1} \mathrm{n}+{ }^{235} \mathrm{U} \rightarrow{ }^{236} \mathrm{U} \rightarrow{ }^{247} \mathrm{La}+{ }^{87} \mathrm{Br}+2^{1} \mathrm{n}$.

As the reactor is operated, fissile (fissionable) ${ }^{239} \mathrm{Pu}$ is produced by neutron absorption in ${ }^{238} \mathrm{U}$.

${ }^{218} \mathrm{U} \frac{(\mathrm{n}, \gamma)}{{ }^{239} \mathrm{U}} \frac{\beta^{-}}{23.5 \mathrm{~m}}{ }^{239} \mathrm{~Np} \frac{\beta^{-}}{2.35 \mathrm{~d}}{ }^{239} \mathrm{Pu}$.

As suggested in Fig. 2. a self-sustaining chain reaction will need only one of the several neutrons produced per fission to cause another fission. ${ }^{1}$ The interaction of fission-produced neutrons with matter is also illustrated in Fig. 2. Because an average fission event produces two or three neutrons, surplus neutrons are available for "capture" by the fuel itself, a lithium-containing target, the reactor structures. and the coolant. Reacting with the

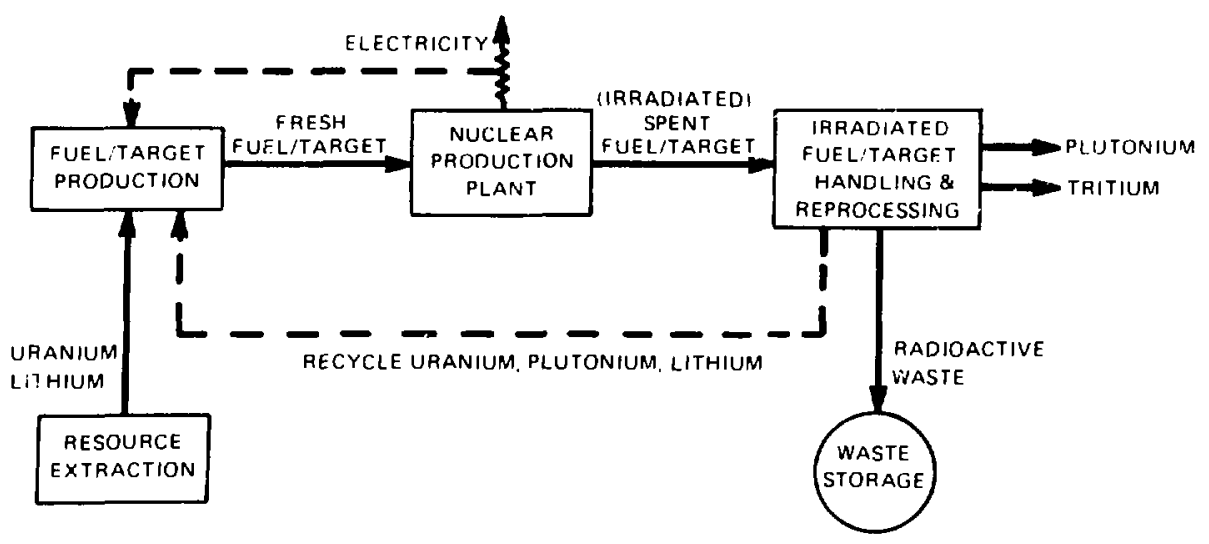

Fig. 1.

Generalized defengs fuel cycle. 


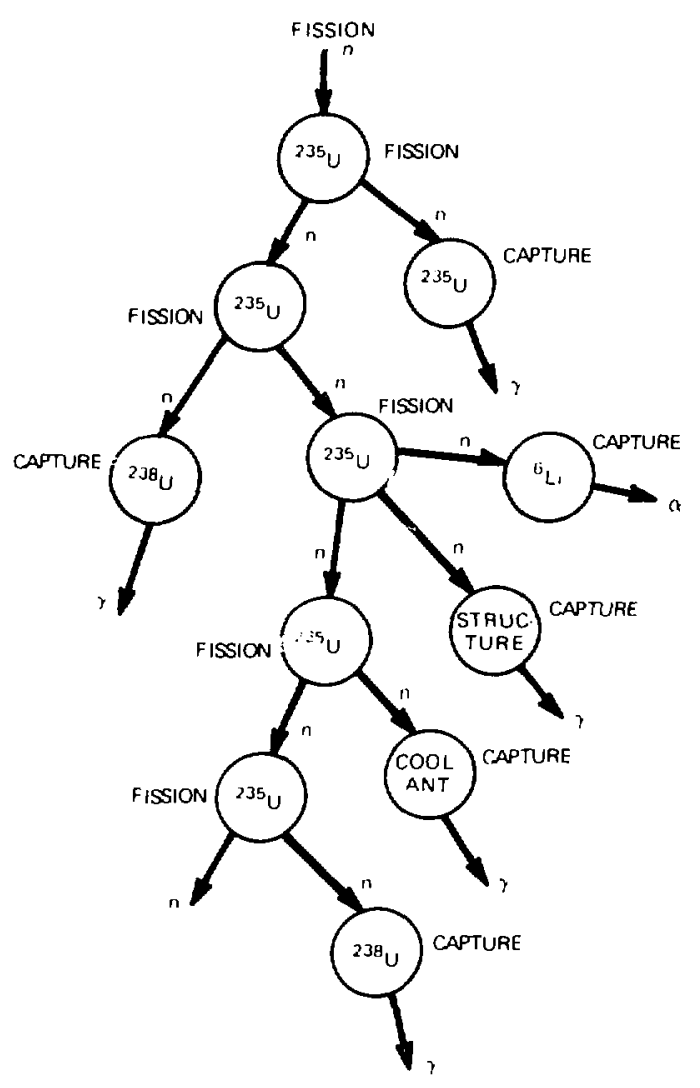

Fig. 2.

Fission-produced neutrons in a chain reaction and their interactions with matter.

${ }^{6} \mathrm{Li}$-containing target, some of these neutrons will yield tritium,

${ }^{6} \mathrm{Li}+{ }^{\mathrm{H}} \rightarrow{ }^{4} \mathrm{He}+\mathrm{T}$,

where ${ }^{4} \mathrm{He}$ is in the form of energetic alpha particles. Thus, the concentration of ${ }^{239} \mathrm{Pu}$ and tritium builds up in the reactor during the life of fuel and target. $\mathbf{A}$ wide range of actinides (highly radioactive fission product elements) is also produced by neutron absorption processes in the fuel. ${ }^{2}$ The absorption of neutrons not entering into fission reactions can eventually build up significant quantities of transuranic (TRU) elements (actinides of higher atomic number). Because these are increasingly higher order processes, greater production of higher isotopes occurs with greater fuel burnup and thermally fissile plutonium isotopes, ${ }^{239} \mathrm{P}_{\mathrm{u}}$ and ${ }^{241} \mathrm{Pu}$, are mixed with other isotopes, ${ }^{240} \mathrm{Pu}$. ${ }^{242} \mathrm{Pu}$, and ${ }^{238} \mathrm{Pu}$.

The so called "back end" of the fuel cycle involves handling of spent fuel and target, chemical reprocessing to separate plutonium and tritium, recycling for fuel and target production, and radioactive waste disposal. In theory, the back end of the defense fuel cycle could reprocess spent fuel and target from commercial reactors, returning fresh assemblies and maintaining a satisfactory inventory of defense materials. This alternative could be viable only if the US policy of separating civilian and defense fuel cycles were to change. Public concern about plutonium proliferation and safeguards might thereby be dissipated. Further details of production and reprocessing related to such a cooperative system are discussed in Sec. III.A.1. and in Appendices $A$ and $B$. This option is similar to the multi-national arrangements being considered in Europe. In time, the US might adopt such an approach for a national fuei cycle: however, this system can not be assured of operation for the 1990s, and therefore it is not included in the following section.

\section{ALTERNATIVES TO THE PROPOSED RE- PLACEMENT PRODUCTION REACTORS}

\section{A. Existing Commercial Reactors}

1. Production Capability. The dominant type of commercial reactor in the US is the light-water reactor (LWR). The two varieties of LWRs, the pressurized water reactor (PWR) and the boiling water reactor (BWR), are illustrated in Figs. 3 and 4 . Light water (ordinary water, $\mathrm{H}_{2} \mathrm{O}$ ) is used in an LWR as both moderator and coolant; fuel is in the form of narrow rods. Fission neutrons escape the rods, are slowed in the water, and then diffuse back into the rods where they induce new fissions.

Present day LWRs are fueled with uranium whose content of fissile ${ }^{235} \mathrm{U}$ has been enriched to $2.5-3 \%$. It is also possible to operate $\mathrm{LWR}$ s by adding fissile ${ }^{239} \mathrm{Pu}$ or ${ }^{233} \mathrm{U}$ to its fissile fuel content. Table II lists characteristics of a model 1000-MW(e) PWR and BWR. ${ }^{1.2}$

PWR fuel consists of small pellets of sintered $\mathrm{UO}_{2}$ placed in 0.01 -m-diam and 4-m-long zircalloy tubes that are bundled into fuel rod assemblies, typically in a square array of $15 \times 15$. BWR fuel rods with pellets of sintered $\mathrm{UO}_{2}$ are about $0.015 \mathrm{~m}$ in diameter and are assembled into $7 \times 7$ or $8 \times 8$ arrays. 


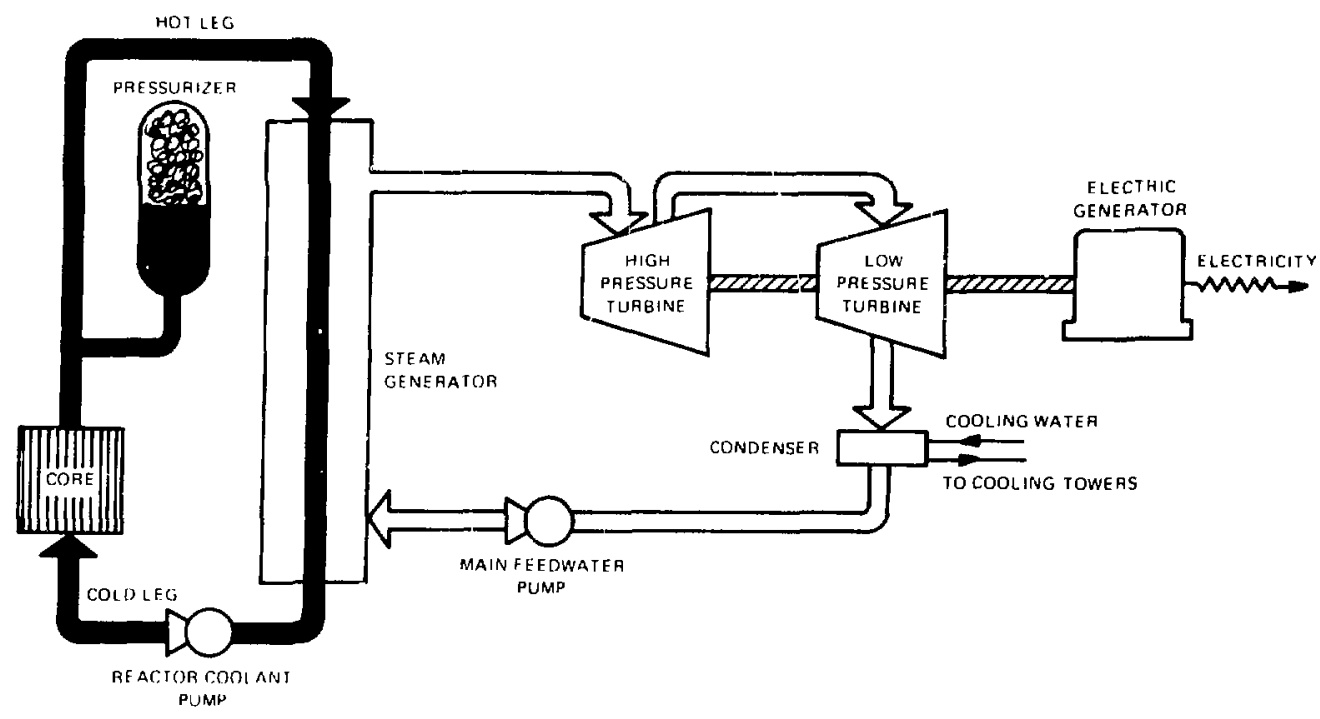

Fig. 3.

The PWR concept.

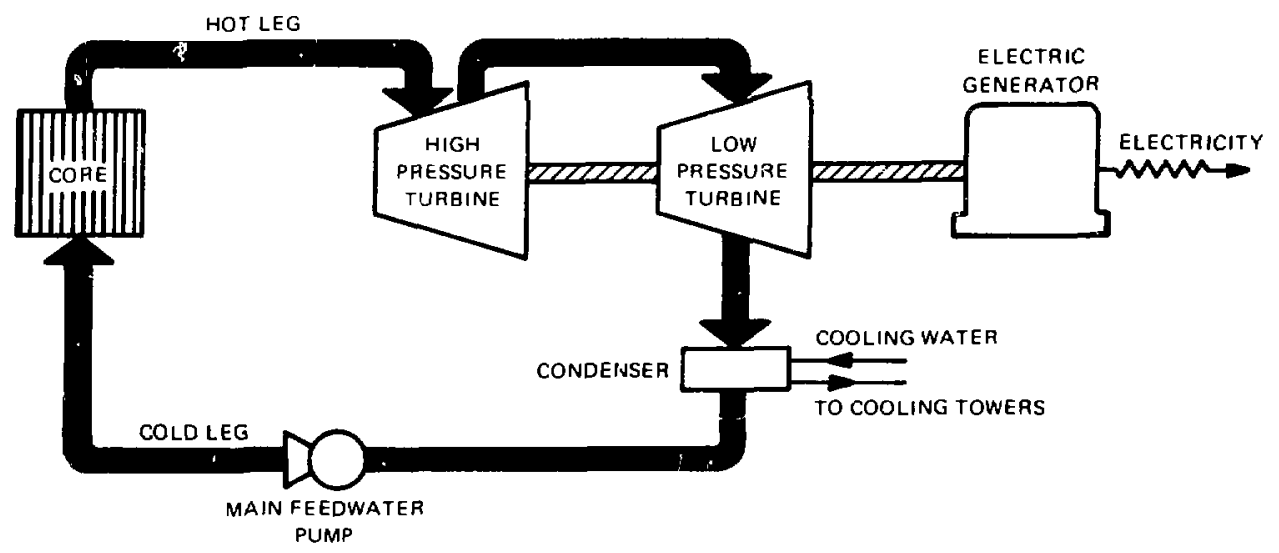

Fig. 4.

The BWR concept.

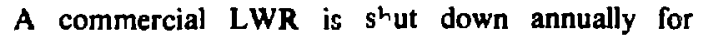
refueling; one-third of a PWR core and one-fourth of a BWR core are replaced at each fueling. Typical isotopic composition of plutonium in tischarged LWR fuel is given in Fig. 5. Exact values depend on individual reactor design, operation, and initial fuel composition. ${ }^{3.4}$ Table III(a) lists nominal plutonium isotope composi- tions of spent fuel from $\mathrm{UO}_{2}$-fueled $\mathrm{BWRs}$, based on calculations using a $3.2 \%{ }^{235} \mathrm{Pu}$ enrichment for a 33 MW-d/kgHM burnup. ${ }^{5,6}$ For comparison, the uranium and plutonium composition of fresh and spent MOX ( $\mathrm{UO}_{2}$ and $\mathrm{PuO}_{2}$, mixed oxide) LWR fuel is also given in Table III(b) for a $33 \mathrm{MW}-\mathrm{d} / \mathrm{kgHM}$ burnup and a fissile $\left({ }^{233} \mathrm{U},{ }^{239} \mathrm{Pu}\right.$, and $\left.{ }^{241} \mathrm{Pu}\right)$ content of $4.1 \%$. 
TABLE II

\section{REPRESENTATIVE CHARACTERISTICS \\ OF A COMMERCIAL LWR"}

\begin{tabular}{|c|c|c|}
\hline & PWR & BWR \\
\hline Coolant & $\begin{array}{l}\text { Ordinary water } \\
\left(\mathrm{H}_{2} \mathrm{O}\right)\end{array}$ & $\begin{array}{l}\text { Ordinary water } \\
\left(\mathrm{H}_{2} \mathrm{O}\right)\end{array}$ \\
\hline Moderator & $\mathrm{H}_{2} \mathrm{O}$ & $\mathrm{H}_{2} \mathrm{O}$ \\
\hline${ }^{235} \mathrm{U}$ enrichment $(\%)$ & $2-4$ & $2-4$ \\
\hline Fertile (bred) nuclide & ${ }^{238} \mathrm{U}\left({ }^{239} \mathrm{Pu}\right)$ & ${ }^{238} \mathrm{U}\left({ }^{239} \mathrm{Pu}\right)$ \\
\hline Core & Rod assemblies & Rod assemblies \\
\hline $\begin{array}{l}\text { Annual uranium }\left(\mathrm{U}_{3} \mathrm{O}_{8}\right) \\
\text { requirements at } \\
\text { equilibrium (t) }\end{array}$ & 129 & 121 \\
\hline $\begin{array}{l}\text { Lifetime uranium }\left(\mathrm{U}_{3} \mathrm{O}_{8}\right) \\
\text { requirements }(\mathrm{t})\end{array}$ & 4100 & 4020 \\
\hline Net electric power [MW(e)] & 1000 & 1000 \\
\hline Thermal power [MW(th)] & 3077 & 3067 \\
\hline Avg. burnup $[M W($ th) $-\mathrm{d} / \mathrm{kg}]$ & 33.0 & 27.5 \\
\hline Refueling interval (yr) & 1 & 1 \\
\hline
\end{tabular}

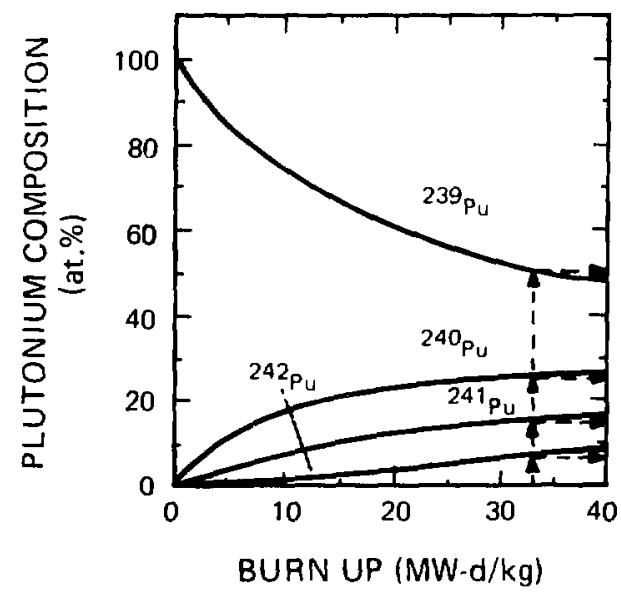

Fig. 5.

Typical amount and isotopic cumposition of plutonium in discharged fuel as a function of burvup in an LWR.
Reference 7 reported that a standard power reactor produces about a kilogram of plutonium per day. These data indicate that fuel design and fuel management can be technically adjusted in existing LWRs to produce plutonium in fuel assemblies and tritium in lithiumcontaining target assemblies at calculable quantities and quality. Electricity production is compromised, however, because of fuel design changes or more frequent refueling to tailor the discharge fuel and target content. For example, the effect of replacing one-ninth of the fuel rods in a PWR core with lithium target rods can be estimated. The power decrease of approximately $10 \%$ could be compensated by an increase in the ${ }^{233} \mathrm{U}$ enrichment in the fuel. If the target rods contained a $95 \%{ }^{6} \mathrm{Li}$ enrichment, about a $10 \%$ greater uranium enrichment is required. Tritium production rate then would be about $0.18 \mathrm{~kg} / \mathrm{yr}$ from target rods in eight instrument wells of existing PWRs. 
TABLE III(a)

\section{URANIUM AND PLUTONIUM COMPOSITION OF FRESH AND SPENT UO ${ }_{2}$ LWR FUEL FOR $33 \mathrm{MW}-\mathrm{d} / \mathrm{kgHM}^{\mathrm{B}}$ BURNIP ${ }^{\mathrm{a}}$}

\begin{tabular}{lcc} 
& $\begin{array}{l}\text { Fresh } \\
\text { Fuel }\end{array}$ & $\begin{array}{l}\text { Spent } \\
\text { Fuel }\end{array}$ \\
\hline Total Uranium (kg/tHM) & 1000 & 956 \\
$\begin{array}{l}\text { Isotopic Composition (weight \%) } \\
{ }^{235} \mathrm{U}\end{array}$ & 3.2 & 0.8 \\
${ }^{236} \mathrm{U}$ & 0 & 0.4 \\
${ }^{238} \mathrm{U}$ & 96.8 & 98.8 \\
Total Plutonium (kg/tHM) & 0 & 9 \\
$\quad \begin{array}{l}\text { Isotopic Composition (weight \%) } \\
{ }^{238} \mathrm{Pu}\end{array}$ & & \\
${ }^{239} \mathrm{Pu}$ & $\ldots-$ & 1.4 \\
${ }^{240} \mathrm{Pu}$ & $\ldots-$ & 55 \\
${ }^{241} \mathrm{Pu}$ & $\ldots-$ & 13 \\
${ }^{242} \mathrm{Pu}$ & $\cdots-$ & 5 \\
Other Actinides (kg/tHM) & 0 & 0.6 \\
\hline
\end{tabular}

TABLE III(b)

\section{URANIUM AND PLUTONIUM COMPOSITION OF FRESH AND SPENT MOX LWR FUEL FOR $33 \mathrm{MW}-\mathrm{d} / \mathrm{kgHM}$ BURNUP}

\begin{tabular}{lcc} 
& $\begin{array}{c}\text { Fresh } \\
\text { Fuel }\end{array}$ & $\begin{array}{l}\text { Spent } \\
\text { Fuel }\end{array}$ \\
\hline Total Uranium (kg/tHM) & 946 & 930 \\
Isotopic Composition (weight \%) & & \\
${ }^{235} \mathrm{U}$ & 0.7 & 0.35 \\
${ }^{236} \mathrm{U}$ & 0 & 0.08 \\
${ }^{238} \mathrm{U}$ & 99.3 & 99.6 \\
Total Plutonium (kg/tHM) & 54 & 33 \\
Isotopic Composition (weight \%) & & \\
${ }^{238} \mathrm{Pu}$ & 1.7 & 4 \\
${ }^{239} \mathrm{Pu}$ & 50 & 36 \\
${ }^{240} \mathrm{Pu}$ & 27 & 31 \\
${ }^{241} \mathrm{Pu}$ & 15 & 18 \\
${ }^{242} \mathrm{Pu}$ & 7 & 11 \\
Other Actinides (kg/t HM) & 0 & 2 \\
\hline
\end{tabular}

adapted from Refs. 5 and 6.
LWRs also could be altered to increase neutron use by introducing heavy water $\left(\mathrm{D}_{2} \mathrm{O}\right)$ into the system immediately after refueling, creating a spectral shift control reactor (SSCR).' $A$ greater portion of neutrons are then absorbed by ${ }^{238} \mathrm{U}$, converting it to ${ }^{239} \mathrm{Pu}$. The uranium use of an SSCR would be similar to that of a (oncethrough) CANDU (discussed in Sec.III.C.1.) or an LWR with uranium and plutonium recycles.

2. Fuel Cycle. Spent fuel rods from existing LWRs contain plutonium, some higher actinides, and a residue of fissile uranium. ${ }^{2}$ In the US, about $4300 \mathrm{t}$ of irradiated spent fue! are being stored now and 74 licensed reactors are discharging spent fuel at the rate of about $900 \mathrm{t}$ per year. ${ }^{8}$ Figure 6 shows the once-through fuel cycle without reprocessing and recycling of valuable uranium and plutonium from spent fuel. This uranium and plutonium can be separated from the fission products and from each other and new reactor fuel elements could then be formed. With this recycling process, the fuel cycle shown in Fig. 7 includes the following individual steps. ${ }^{2,9}$

\section{- Mining}

- Milling

- Refining and conversion

- Enrichment

- Reprocessing of spent fuels to separate and recover uranium and plutonium from radioactive wastes and from one another*

- Conversion of recovered uranium*

- Reenrichment of recovered uranium*

- Conversion (to enriched $U_{6}$ )

- Fabrication of enriched uranium pellets

- Conversion of recovered plutonium to a solid form (ior example. $\left.\mathrm{PuO}_{2}\right)^{*}$

- Combination of recovered plutonium with uranium for making mixed oxide fuel, fabrication of pellets, encapsulation in fuel rods, and assembling into fuel elements

- Spent fuel storage

- High level and transuranic waste storage and disposal*

Nuclear fuel reprocessing is discussed in Appendix A.

A separate cycle is needed to produce tritium from the ${ }^{5} \mathrm{Li}$-containing target. Individual steps of this cycle are given below.

- Mining

- Milling

-These operations are omitted in the once-through fuel cycle. 


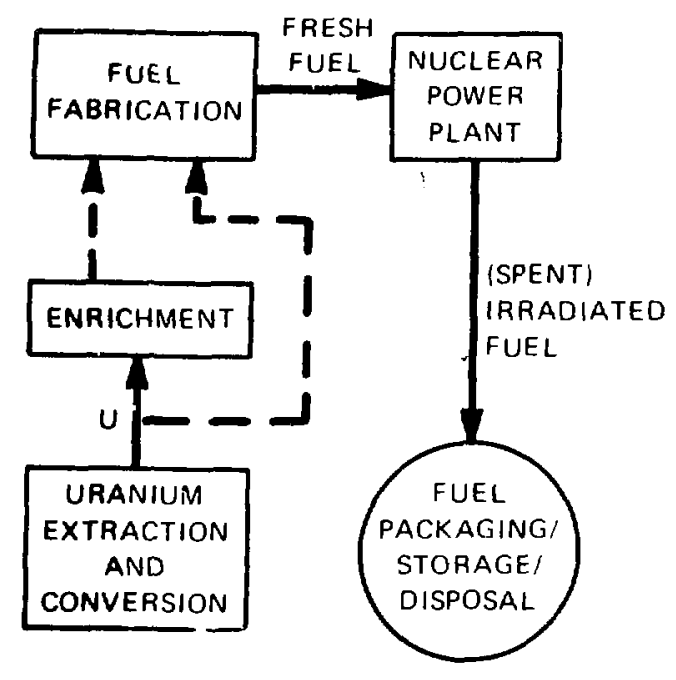

Fig. 6.
- Refining and conversion

- Reprocessing of spent target to separate and recover lithium and tritium from radioactive wastes and from one another

- Conversion of recovered lithium

- Reenrichment of recovered lithium

- Conversion (to lithium alloy or compound)

- Fabrication of target rods and assembly into target elements

- Tritium storage

- Spent target storage

- Waste storage and disposal

After transportation from the reactors, fuel and target could be processed to separate plutonium and tritium at existing reprocessing facilities at SRP, Idaho Falls, and the Barnwell Nuclear Fuel Plant (BNFP). Transportation in the civilian nuclear fuel cycle is discussed in Appendix B. $^{6}$

Once-through nuclear fuel cycie.

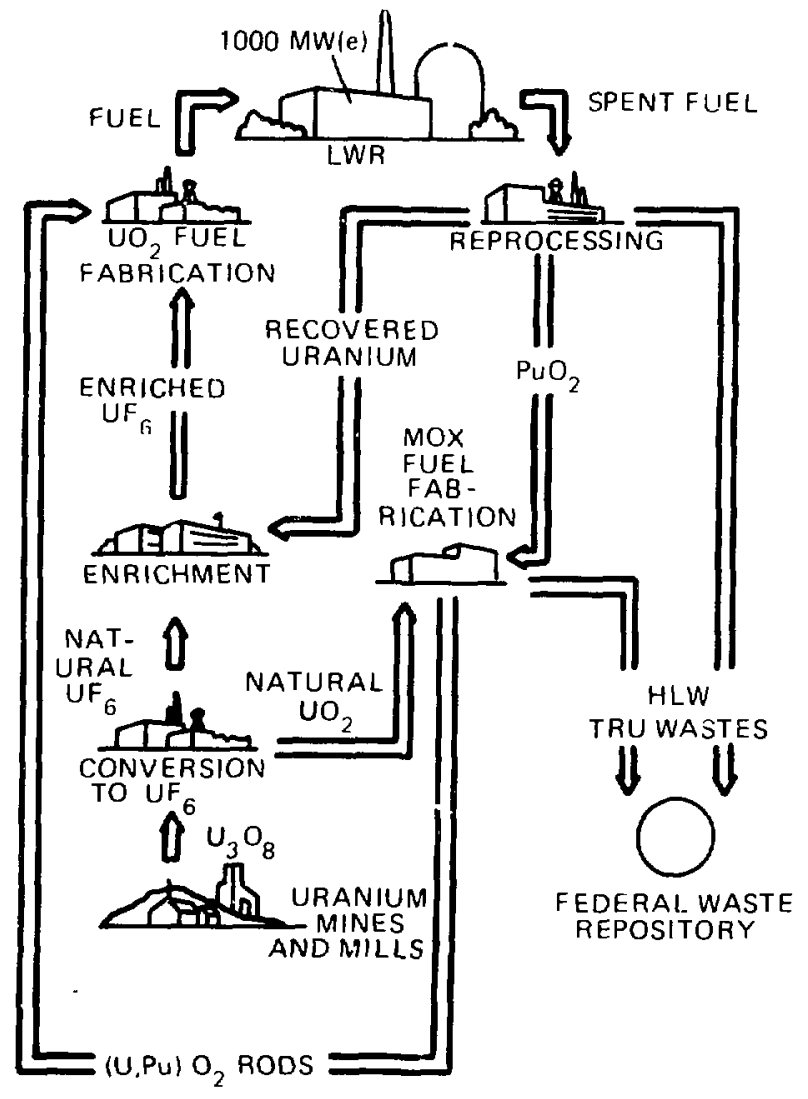

Fig. 7.

LWR fuel cycle with uranium-plutonium recycle. 
The plant at Three Mile Island, Pennsylvania, is an example of how a commercial reactor could be used for the defense fuel cycle although it might be temporarily idle for political reasons. ${ }^{1 C}$ Unit 1 could be operated for production of electricity $[800 \mathrm{MW}(\mathrm{e})]$ and defense materials while the needed repairs were being completed in Unit 2.

\section{B. Existing and Planned Government-Owned Facilities}

1. Production Capability. The potential production capability of existing and planned government-owned facilities was investigated, including demonstration, test, research, and training reactors. The results of a study of DOE facilities are listed in Table IV (Ref. 11). Based on this study, the currently operating Fast Flux Test Facility (FFTF) and planned Clinch River Breeder Reactor Plant (CRBRP) show potential for material output in the next century. Both FFTF and CRBRP are liquid metal (conled) fast breeder reactors (LMFBR). The fast neutrons produced in an LMFBR can produce a larger numbe: of fission neutrons upon absorption by fissile materials than can thermal (slower) neutrons in an LWR.

FFTF, a liquid sodium-cooled, fast test reactor located at HEDL. uses mixed oxide fuel (a mixture of plutonium oxide and depleted uranium oxide) in 0.0058 m-diam fuel pins cladjed by stainless steel 316 (SS 316). Two hundred and seventeen pins are bundled in a fuel assembly in a hexagonal array. The rated power level is $400 \mathrm{MW}$ (th) without electricity generation capability. Table $V$ lists the characteristics of FFTF. Designed for a 30-year lifetime, it reached criticality in 1980 and is currently used for fast reactor fuels and materials testing.

Although using FFTF for defense materials production is feasible, the production rate will be low, for example, $44 \mathrm{~kg}$ of plutonium or $0.5 \mathrm{~kg}$ of tritium per year. Because it is lccated in the same government reservation as the N-Reactor and the Hanford Pures Plant, it might be possible to reprocess fuel and target assemblies there. How ' $x^{\prime}$ er, this would require expansion and inodification of the Purex plant.

CRBRP is to be a demonstration LMFBR with a power level of $975 \mathrm{MW}($ th) and $375 \mathrm{MW}$ (e) (see Fig. 8 and Table V). Its fuel elements are similar to the FFTF fuel assemblies; in addition, blanket assemblies are scattered heterogeneously throughout the core, using pins consisting of derleted uranium $\left({ }^{238} \mathrm{U}\right)$. It is technically feasible to use CRBRP for defense materials production in addition to electric power generation. Estimated plutonium or tritium production is about 210 $\mathrm{kg}$ and $2.6 \mathrm{~kg}$ per year, respectively, but could be optimized to $340 \mathrm{~kg}$ and $4.3 \mathrm{~kg}$ per year. Another alternative might involve tritium production by an accelerator located with CRBRP at Oak Ridge, Tennessee, using electric power generated by CRBRP to produce plutonium (see Appendix $\mathrm{C}$ discussion).

Other government-owned facilities such as training reactors and naval reactors owned by DoD were investigated for production capability. Because these reactors are used for other DoD programs and are highly optimized for small power generation, infrequent refueling, and highly enriched fuel, they are not good candidates for production of defense materials.

2. Fuel Cycle. Table $V$ also lists the characteristics of a commercial scale LMFBR for comparison with FFTF and CRBRP. The LMFBR development was planned to help extend natural resources indefinitely by establishing a plutonium economy as illustrated in Fig. 9. The Atomic Energy Commissior: (AEC) began groundwork in the late 1950s, and US long-range plans anticipated commercial use of mixed oxide fuels in LWRs by the $1980 \mathrm{~s}^{2}$ In the early 1960 s the first commercial uranium and plutonium reprocessing plants were built and operated by Nuclear Fuel Services at West Valley, New York, and by Eurochemic in Mol, Belgium. Larger reprocessing plants with improved fuel-handling technology were built in the early 1970s at Barnwell, South Carolina, and La Hague, France. Research was also initiated to solve the problems of treatment and permanent storage or disposal of nuclear waste.

Assuming a 30-day decay time, a 1000-MW(e) LMFBR core loaded with depleted uranium plus recycled plutonium and uranium typically will have the isotopic composition of extracted plutonium shown in the following table.

\begin{tabular}{crc} 
Pu & \multicolumn{1}{c}{$\%$} & $\mathrm{~kg}$ \\
\hline 236 & $2 \times 10^{-6}$ & $3 \times 10^{-5}$ \\
238 & 0.1 & 1.4 \\
239 & 71.6 & 1460.6 \\
240 & 25.1 & 510.8 \\
241 & 2.4 & 48.4 \\
242 & 0.8 & 15.5 \\
\hline Total & $100 \%$ & $2037 \mathrm{~kg}$
\end{tabular}




\section{TABLE IV}

\section{PRODUCTION CAPACITY OF DOE-OWNED REACTORS}

\begin{tabular}{|c|c|c|c|c|c|c|c|c|c|c|c|c|c|c|c|c|c|}
\hline Resctor & Letworatory & Fuel & $\begin{array}{l}\text { Fuel } \\
\text { Type }\end{array}$ & Coolant & Reflector & $\begin{array}{l}\text { Opsration } \\
\text { Life }\end{array}$ & $\begin{array}{l}\text { Plant } \\
\text { Aving- } \\
\text { ability }\end{array}$ & $\begin{array}{l}\text { Program- } \\
\text { matic } \\
\text { Aveil- } \\
\text { ability } \\
\end{array}$ & $\begin{array}{l}\text { Thermal } \\
\text { Power } \\
\text { [MW(th)] }\end{array}$ & $\begin{array}{l}\text { Optimal } \\
\text { Converaton } \\
\text { Ratio } \\
\end{array}$ & $\begin{array}{l}\text { Optimul Pu }{ }^{2} \\
\text { Production } \\
\text { (kx/yr) }\end{array}$ & $\begin{array}{l}\text { Optumal T" } \\
\text { Production } \\
\text { (kg/yr) }\end{array}$ & $\begin{array}{l}\text { Contidence } \\
\text { Fictor for } \\
\text { Optimal } \\
\text { Production }\end{array}$ & $\begin{array}{l}\text { Beat Exsimate } \\
\text { Pu Production } \\
(\mathrm{k} / \mathrm{yr})\end{array}$ & $\begin{array}{l}\text { Beat Extimuteb } \\
\text { T Praduction } \\
\text { (ke/yr) }\end{array}$ & $\begin{array}{l}\text { Cunfidence } \\
\text { Fetor for } \\
\text { Best Estimate } \\
\text { Production }\end{array}$ & $\begin{array}{l}\text { Annual } \\
\text { Operating } \\
\text { Coets } \\
\text { (Mition S }\end{array}$ \\
\hline$\overline{\text { CRBRP }}$ & $\begin{array}{l}\text { Oak Ridge } \\
\text { Tenu. }\end{array}$ & $\mathbf{P u}^{c}$ & $\begin{array}{l}\text { Oxide } \\
\text { Pellets }\end{array}$ & Na & $231 \mathrm{U}$ & $1985 / 2015$ & 0.75 & $\begin{array}{l}0.0 \text { or } \\
1.0\end{array}$ & 975 & 1.20 & 340 & 4.3 & $<0.5$ & 210 & 26 & 0.73 & $\begin{array}{c}\text { Not } \\
\text { sveiluble }\end{array}$ \\
\hline FFTF & HEDL & Pú & $\begin{array}{l}\text { Oxide } \\
\text { Pellets }\end{array}$ & Na & $\begin{array}{l}\text { Stainkeas } \\
\text { Steel }\end{array}$ & 1981/201! & 0.75 & 0.5 & 400 & 1.20 & 140 & 1.8 & $<0.5$ & 44 & 0.5 & 0.75 & 75 \\
\hline LWBR & $\begin{array}{l}\text { Shipping } \\
\text { Port }\end{array}$ & ${ }^{233} \mathrm{U}$ & Oxide & $\mathbf{L W}$ & Thoria & $1977 / 1985$ & 0.70 & 0 & 236 & 1.00 & -- & $\cdots$ & $\cdots$ & $\cdots$ & $\cdots$ & $-\cdots$ & $\ldots$ \\
\hline ATR & INEL & $\begin{array}{l}{ }^{93 \%} \\
{ }^{23} \mathrm{U} \\
\end{array}$ & $\begin{array}{l}\text { Al/U } \\
\text { meral }\end{array}$ & LW & $B=$ & $1967 / 2007$ & $0.7 \overline{0}$ & 6.2̂ิ̂ & 250 & 0.80 & 35 & 0.7 & $<0.3$ & 1.6 & 0.04 & 0.8 & 15 \\
\hline ETR & INEL & $\begin{array}{l}93 \% \\
{ }^{935} \mathrm{U}\end{array}$ & $\begin{array}{l}\text { Allu } \\
\text { metal }\end{array}$ & LW & Be & 1957/1987 & 0.90 & 1.00 & 175 & 0.80 & 49 & 0.6 & $<0.3$ & 7.1 & 0.18 & 0.8 & 7 \\
\hline HFIR & ORNL & $\begin{array}{l}\frac{93 \%}{215} \mathrm{U} \\
{ }^{215}\end{array}$ & $\begin{array}{l}A / U \mathrm{U} \\
\text { metal }\end{array}$ & $\mathbf{L W}$ & Be & $1965 / 1995$ & 0.94 & 0.50 & 100 & 0.80 & 29 & 0.4 & 0.4 & 6.7 & 0.17 & 0.9 & 4 \\
\hline EBR-JI & ANL-W & $\begin{array}{l}67 \% \\
{ }^{635} \mathrm{U}\end{array}$ & $v$ mets & $\mathrm{Na}$ & $\begin{array}{l}\text { Stuintess } \\
\text { Sted }\end{array}$ & $1961 / 1991$ & 0.70 & 1.00 & 625 & 1.00 & 17 & 0.2 & $<0.3$ & $\ldots$ & --- & $\cdots$ & 16 \\
\hline LOFT & INEL & $U$ & Oxide & LW & $\mathbf{L W}$ & $1978 / 1988$ & 0.70 & 1.00 & 50 & 0.80 & 11 & 0.1 & $<0.2$ & - & -- & $\cdots$ & 40 \\
\hline HFBR & BNL & $\begin{array}{l}93 \% \\
{ }^{939} \mathrm{U}\end{array}$ & $\begin{array}{c}\text { AV } \\
\text { cermat }\end{array}$ & HW & HW & I965/1995 & 0.80 & 0.65 & 40 & 0.80 & 10 & 0.1 & $<0.3$ & 1.0 & 0.02 & 0.8 & 2.3 \\
\hline \multirow[t]{2}{*}{ ORR } & \multirow[t]{2}{*}{ ORNL } & \multirow{2}{*}{$\begin{array}{l}{ }^{93 \%} \mathrm{U} \\
{ }^{933} \mathrm{u}\end{array}$} & \multirow{2}{*}{$\begin{array}{c}\mathrm{Al}_{2} \mathrm{O}_{3} \\
\text { cermmat }\end{array}$} & \multirow[t]{2}{*}{ LW } & \multirow[t]{2}{*}{ Be } & \multirow[t]{2}{*}{$1958 / 1988$} & \multirow[t]{2}{*}{0.85} & 1.00 & 30 & 0.80 & 8 & 0.1 & $<0.3$ & 1.2 & $\underline{0.03}$ & 0.3 & 1.5 \\
\hline & & & & & & & & Total & 2318 & & 659 & 8.3 & & 272 & 3.5 & & \\
\hline \multirow{2}{*}{\multicolumn{3}{|c|}{$\begin{array}{l}\text { Other (91 research reactors } \\
\text { wihh individual power } \\
\text { ratings kess than } 30 \mathrm{MW} \text { ) }\end{array}$}} & & & $\cdots$ & $\cdots$ & $\cdots$ & $\cdots$ & 121 & & 26 & .3 & & & & & \\
\hline & & & & & & & \multicolumn{2}{|c|}{ Totels } & 2439 & & 685 & 8.6 & & & & & \\
\hline
\end{tabular}

atinges kess then 30 mW

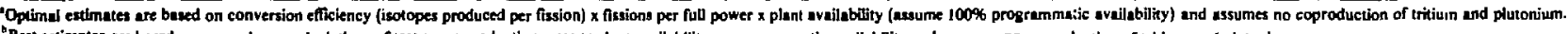

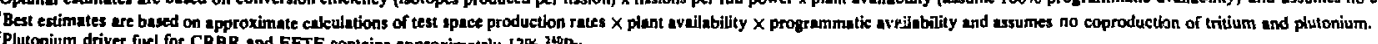




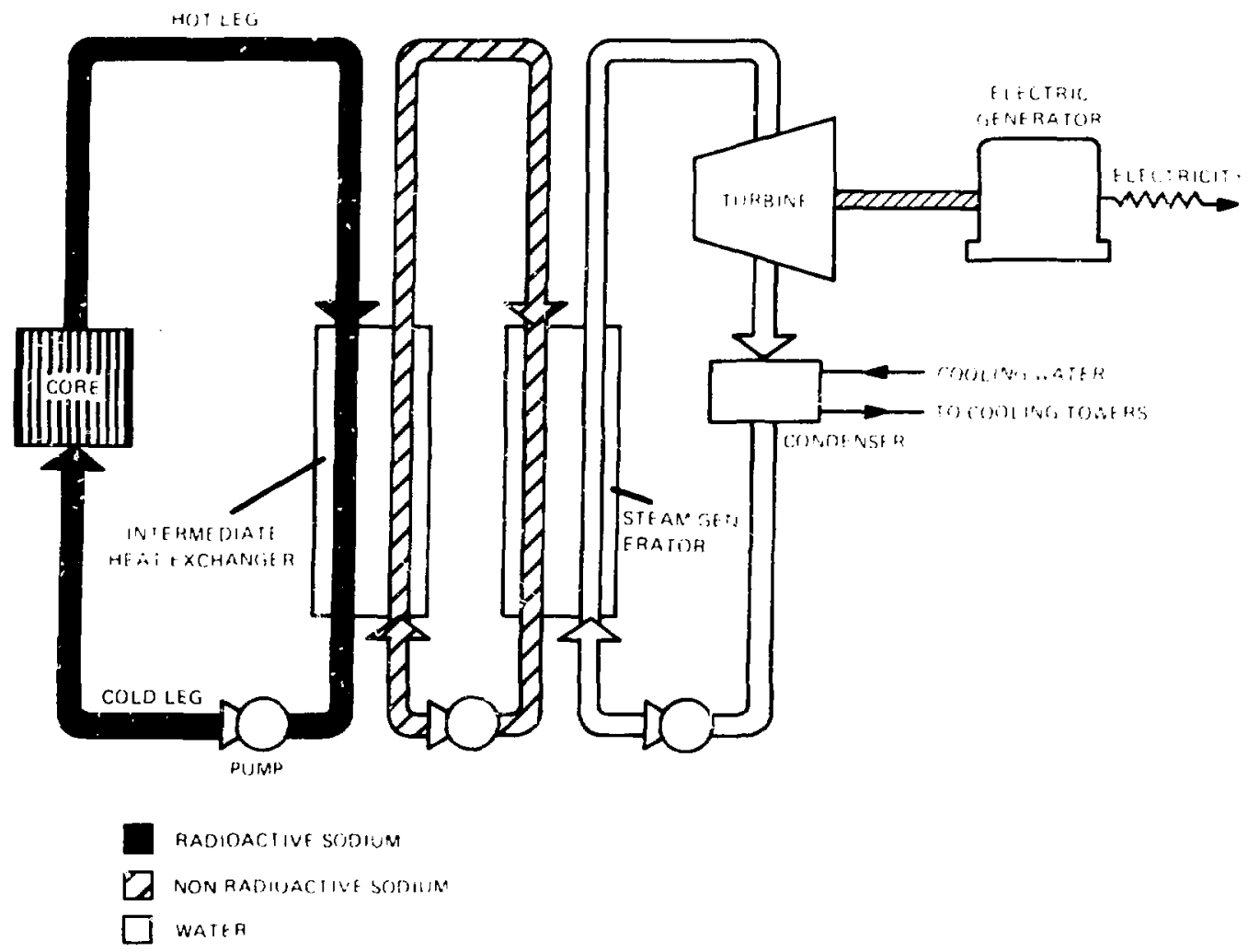

Fig. B.

An LMFBR plant.

From this table we can estimate the plutonium pro duction of CRBRP by using a scale factor of 0.375 . based on the power production: $548 \mathrm{~kg}$ of ${ }^{114} \mathrm{Pu}$ per year, compared with $210 \mathrm{~kg}$ in Ref. 11.

Existing reprocessing facilities at SRP. Idaho Falls, and BNFP are candidates for fuel processing, plutonium separation, target focessing, and tritium sepasation. Associated costs of such an operation should be evaiuated.

\section{Other Concepts}

Commercial HWRs promise great production potential for defense materials. Future alternatives $\mathrm{n}_{\mathrm{L}}, \because$ also include fusion-fission reactors for coproduction of plutonium and tritium and pure fusion reactors and accelerators for tritium production-both of which will be discussed in Appendix $C$.
1. Production Capability. Heavy water as a moderator has some advantages for thermal reactors because it has a lower capture cross section than that of light water. The improvement in ueutron economy allows use of natural uraniurn as a juel, eliminating the need for enrichrient and thereby simplifying the use of other fissile materials as fuel. ${ }^{2}$ variety of HWRs, including Fugen. Cirene. Atucha, CANDL, and SGHWR, have been developed throughout the world. ${ }^{12}$ The only commercial HWR at present is the CANDU, designed and developed by Atomic Energy of Canada, Ltd. Figure 10 show's CANDU's fuel and heavy-water coolant confined to a system of pressure tubes, with a heavy-water moderator at low pressure in the interyening spaces. The heavy-water coolant nows through the fuel channels and produces steam with ordinary water in the steam generators.

A typical CANDU fuel bundle consists of an array of rods that are considerably larger than those for an LWR 
TABLE V

\section{COMPARISON OF LIQUID METAL FAST BREEDER PARAMETERS"}

\begin{tabular}{|c|c|c|c|}
\hline Design Parameter: & EFTF & CRBR & $\begin{array}{l}\text { Commercial and } \\
\text { Commercial } \\
\text { Prototype } \\
\end{array}$ \\
\hline Thermal power $[\mathbf{M W}(\mathrm{th})]$ & 400 & 975 & 3800 \\
\hline Net electric power [MW(e)] & $\cdots$ & 350 & 1500 \\
\hline Overall plant efficiency (\%) & $\cdots$ & 35.9 & 39.5 \\
\hline Number of primary loops & 3 & 3 & 3 \\
\hline $\begin{array}{l}\text { Containment diameter/depth } \\
\text { below operating floor/height } \\
\text { above operating floor }(\mathrm{m})\end{array}$ & $41 / 24 / 33$ & $57 / 26 / 52$ & $51 / 26 / 50$ \\
\hline Fuel material & Oxide & Oxide & Oxide \\
\hline Cladding materia! & SS 316 & SS 316 & $\begin{array}{l}\text { Low swelling/ } \\
\text { SS } 316\end{array}$ \\
\hline Fuel rod diameter (m) & 0.0058 & 0.0058 & 0.0069 \\
\hline Fuel rod pitch/diameter ratio & 1.26 & 1.26 & 1.24 \\
\hline Number fuel rods/assembly & 217 & 217 & 271 \\
\hline Number fuel assemblies & 76 & 198 & 318 \\
\hline Number blanket assemblies & None & 150 & 234 \\
\hline Number control/safety assemblies & $6 / 3$ & $15 / 4$ & $27 / 4$ \\
\hline Core height/diameter $(\mathrm{m})$ & $0.91 / 1.22$ & $0.91 / 1.89$ & $1.22 / 3.1$ \\
\hline Peak fuel burnup (MW-d/kg) & 80 & 150 & 150 \\
\hline Breeding ratio & $\cdots$ & 1.2 & 1.25 \\
\hline Doubling time $(y r)$ & $\cdots$ & 23 & $12 / 15$ \\
\hline Vessel diameter/length (m) & $6.31 / 13.35$ & $6.31 / 16.40$ & $7.16 / 18.14$ \\
\hline
\end{tabular}

and contains natural uranium rather than enriched $\mathrm{UO}_{2}$. The low fuel burnup in natural uranium requires frequent fuel rod replacement, but the $C$ anadian design allows for continuous refueling without shutting down the reacior. Thermal efficiency is $30 \%$, lower than that for LWRs (which is about $33 \%$ ).

A 1000-MW(e) CANDU contains abuut 130 i of natural uranium, as $\mathrm{UO}_{2}$, in 0.012 -m-diam $\mathrm{Zr}-\mathrm{Nb}$ cladded rods that are assembled in circular arrays of 37 rods per assembly. Operating with natural uranium, with only $0.7 \%{ }^{233} \mathrm{U}$, annual fuel burnups are about $7.5 \mathrm{MW}$. $\mathrm{d} / \mathrm{t}$. The annual natural uranium charge has a fissile content of about $940 \mathrm{~kg}$, and the annual discharge contains about $220 \mathrm{~kg}{ }^{233} \mathrm{U}$ and $350 \mathrm{~kg}$ of ${ }^{239} \mathrm{Pu}$. Table
VI shows annual production and characteristics of material for uranium-fueled CANDU reactors with (1) no recycle and (2) a self-generated plutonium recycle for equilibrium fuel cycles.

Significant tritium production occurs in the heavy. water moderator because of seutron activation of the heavy water $(D+' n \rightarrow i+\gamma)$ as shown in Fig. 2 . Approximately $0.1 \mathrm{~kg} / \mathrm{yr}$ of tritium is generated at steady state after approximately $15 \mathrm{yr}$ of operation in a 1000 MW(e) reactor. ${ }^{13}$ Ontario Hydro, a Canadian power company, is developing a tritium removal and recovery system from the moderator and estimates a total cumulative production potential of $39.6 \mathrm{~kg}$ of tritium during the life of the eight Pickering reactors. 


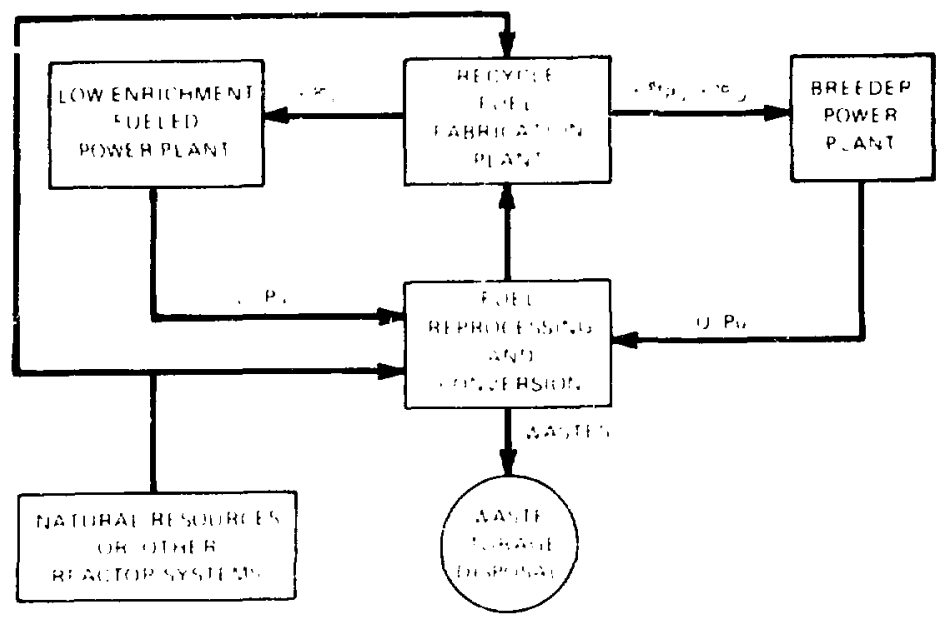

Fig. 9.

Fuel cycle for plutonium economy.

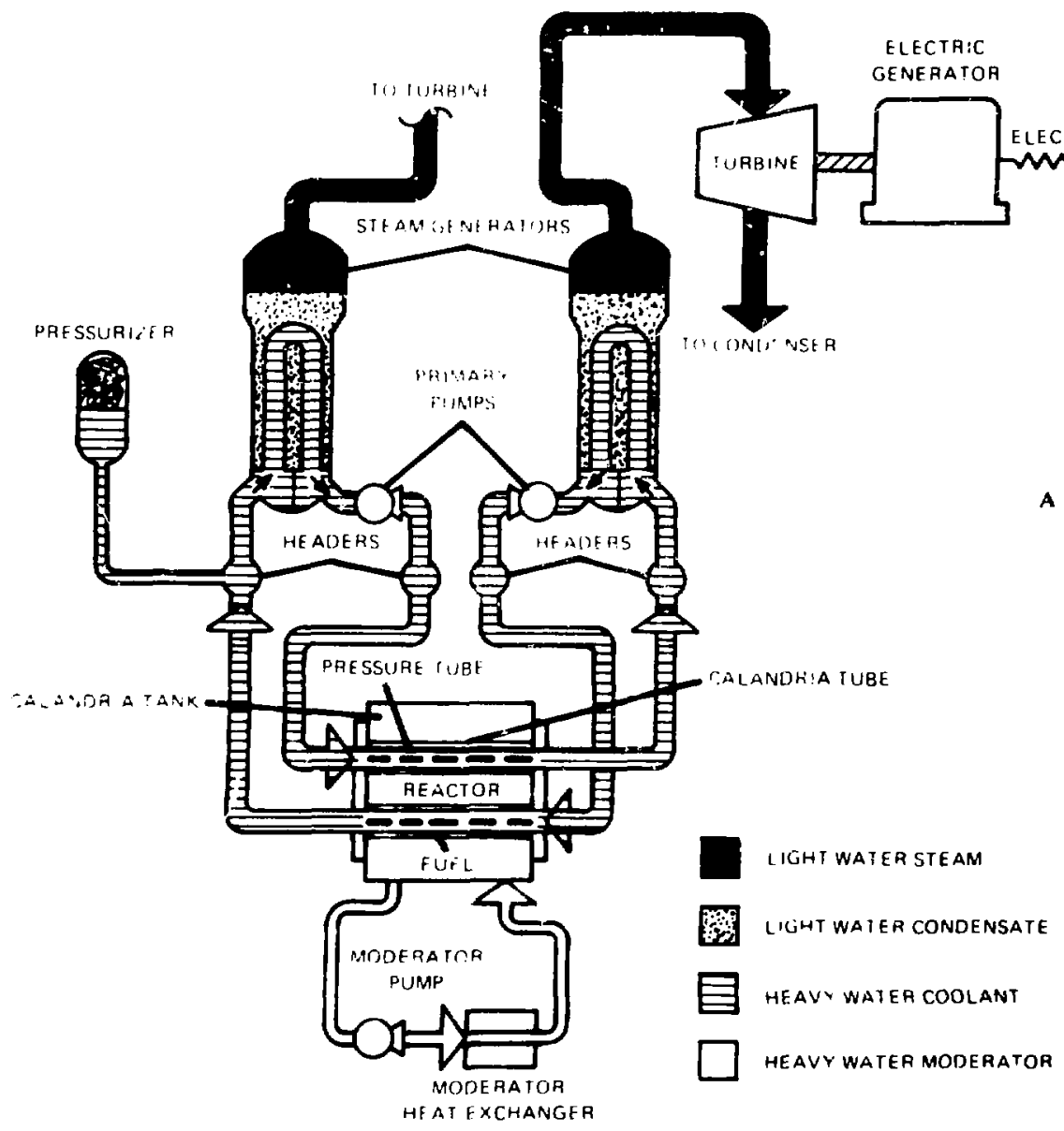

Fig- 10.

A CANDU power plant. 
TABLE V]

INPUT-OUTPUT CHARACTERISTICS

OF A 1000-MIV(e) URANIUM-FUELED CANDU

REACTOR WITH (!) NO RECYCLE AND (2)

A SELF-GENERATED PLUTONIUM RECYCLE

(1)

$\begin{array}{ll}\text { Natural uranium } & 131 \mathrm{t} \\ \text { Fuel burnup } & 7.5 \mathrm{MW}-\mathrm{d} / \mathrm{kg} \\ \text { Spent fuel composition } & \\ { }_{23 .} \mathrm{U} & 0.17 \% \\ \text { Fissile } \mathrm{Pu}^{\circ} & 0.27 \%\end{array}$

(2)

Natural uraniura

$60 i$

Fuel burnup

Spent fuel reprocessed

Fission products

${ }^{238} \mathrm{U}$

Recycled $\mathrm{Pu}^{\mathrm{b}}$

$1.008 \mathrm{t}$

$58.3 \mathrm{t}$

$0.187 \mathrm{t}$

${ }^{\text {t} A d a p t e d ~ f r o m ~ R e f . ~ 2, ~ e q u i l i b r i u m ~ f u e l ~ c y c l e ~ a s s u m e d . ~}$
To increase tritium production, a fraction of the fuel assemblies can also be replaced by target assemblies containirg ${ }^{\circ} \mathrm{Li}$. as in other reactors. However, this would mean two ititium separation facilities, one for the moderator and another for the target.

CANDU reactors are noi licensed in the US. However. a conceptual design of a large heavy-water reactor

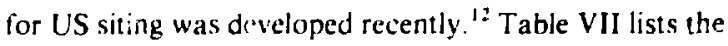
design parameters of this pressurized HWR. Various studies on licensing of CANDUs have concluded that there is no reason why the HWR should not be licensable in the US. ${ }^{12.1414}$

2. Fuel Cycle. Table VIl indicates the CANDU fuel cycle with a self-generated plutonium recycle. ${ }^{2}$ Reference 1 reported that annual discharge of fissile plutonium in spent fuel from the slightly enriched HWR core is lowe: than that discharged from the LWR and is less than half the discharge of the natural uranium-fueled system. Thus, it is easier to optimize a natural urarium-fueled HWR for maximum plutonium production. Such a reactor, however. has the highest uranil:m ore requirements, as shown in Fig. $11 .^{\text {ir }}$

${ }^{\mathrm{t}}$ Fissile $\mathrm{Pu}:{ }^{210} \mathrm{Pu}$ and ${ }^{211} \mathrm{Pu}$.

TABLE VII

DESIGN PARAMETERS OF AN HWR FOR US SITING

\begin{tabular}{ll}
\hline $\begin{array}{l}\text { Output } \\
\text { rotal fission }\end{array}$ & $4029 \mathrm{MW}$ \\
gross electrical & $1344 \mathrm{MW}$ \\
net electrical & $1260 \mathrm{MW}$ \\
Coolant & Heavy water $\left(\mathrm{D}_{2} \mathrm{O}\right)$ \\
Moderator & $\mathrm{D}_{2} \mathrm{O}$ \\
$\mathrm{D}_{2} \mathrm{O}$ Inventory & $0.65 \mathrm{VW}(\mathrm{e})$ \\
Pressure tubes & 740 \\
$\quad$ material & $\mathrm{Zr}_{\mathrm{r}} \mathrm{Nb}$ \\
inside diameter & $103.3 \mathrm{~mm}$ \\
wall thickness & $5.79 \mathrm{~mm}$ \\
Active core size (height/diameter) & $5.94 \mathrm{~m} / 8.76 \mathrm{~m}$ \\
Lattice pitch & $0.286 \mathrm{~m}$ \\
Fuel load & $8880 \mathrm{bundles}$ \\
$\quad \mathrm{U}$ & $163 \mathrm{t}$ \\
UO & 185 \\
Fuel bundle (37 elements) & \\
length/diameter & $495.3 \mathrm{~mm} / 102.49 \mathrm{~mm}$ \\
Cladding & $\mathrm{Zr}$ \\
\hline
\end{tabular}




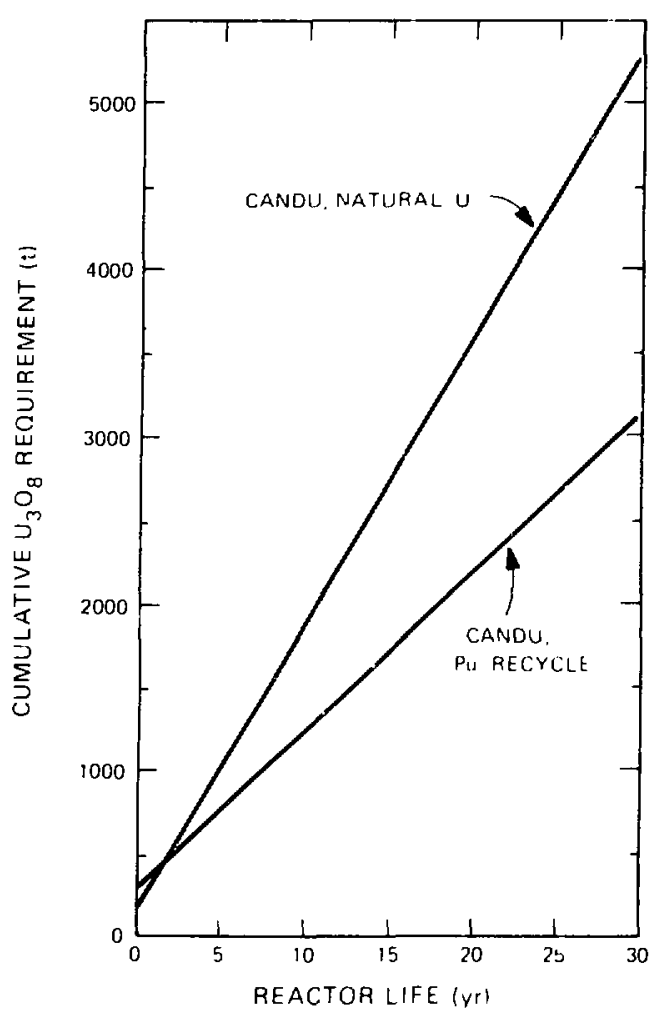

Fig. 11.

Cumulative uranium ore requirements for the CANDL power plant.
Because the present SRP reactors are a low-temperature type HWR, the US has considerable experience with operating and reprocessing fuel and target assemblies for plutonium and tritium production.

\section{iV. DISCUSSION OF ALTERNATIVES}

The features of these various alternatives to RPRs were studied and compared for defense material production on a unit capability basis. A qualitative comparison of the most significant alternatives, that is. existing LWRs, FFTF/CRBRP, and HWRs, is summarized in Table VIII. All alternatives with significant potential also provide electric power production and exhibit flexibility for quantity, quality, and alternate material production. Environmental impact, safety, and fuel cycle economics were estimated to be similar. although a detailed analysis was not performed.

\section{A. Production Capability}

Existing LWR5 and HWRs have high production capabilities because of inherent flexibility for quantity, quality, and alternate defense material products. The FFTF/CRBRP alternative was rated less than high because they produce a lower level of power than does a commercial $L W R$ or $H W R$.

\begin{tabular}{|c|c|c|c|c|}
\hline \multicolumn{5}{|c|}{ TABLE VIII } \\
\hline \multicolumn{5}{|c|}{$\begin{array}{l}\text { QUALITATIVE COMPARISON OF } \\
\text { SIGNIFICANT ALTERNATIVES }\end{array}$} \\
\hline & $\begin{array}{l}\text { Production } \\
\text { Capability }^{b}\end{array}$ & $\begin{array}{c}\text { Product } \\
\text { Assurance }^{\mathrm{c}}\end{array}$ & $\begin{array}{c}\text { Resource } \\
\text { Efficiency }^{\mathrm{d}}\end{array}$ & $\begin{array}{c}\text { Fuel } \\
\text { Cycle }^{e}\end{array}$ \\
\hline Existing LWRs & High & High & $\begin{array}{l}\text { Less than } \\
\text { medium }\end{array}$ & High \\
\hline FFTF/CRBRP & $\begin{array}{l}\text { Less than } \\
\text { high }\end{array}$ & Medium & High & Medium \\
\hline HWRs & High & High & Medium & $\begin{array}{c}\text { Less than } \\
\text { high }\end{array}$ \\
\hline \multicolumn{5}{|c|}{$\begin{array}{l}\text { 'Based on availability at a government-owned site. } \\
\text { 'Production flexibility for quantity, quality, and alternate products. } \\
\text { 'Technology base and state of development (system dependability). } \\
\text { dUranium resource utilization. } \\
\text { 'Fuel fabrication, reprocessing, and waste management. }\end{array}$} \\
\hline
\end{tabular}




\section{B. Production Assurance}

The state of development, and therefore the system dependability, is highest with the LWR. Seventy-four nuclear reactors, with a combined rate capacity of $55000 \mathrm{MW}(\mathrm{e})$, are licensed to operate in the US. HWRs. rated second, are higher than FFTF/CRBRP because nine CANDU reactors already are operating with a total rated power of $3017 \mathrm{MW}(\mathrm{e})$.

\section{Resource Efficiency}

The FFTF/CP.BRP alternative was rated highest in resource efficiency because they are LMFBRs, and can be optimized for minimum moderation (slowing of the neutron energy) to achieve the highest possible yield of fission neutrons per fissile neutron absorption. Thus, uranium resource efficiency is highest with an LMFBR (oxide breeder), followed by CANDUs, and LWRs.

\section{Fuel Cycle}

Fuel cycle technology, that is, fuel fabrication, reprocessing, and waste management, was investigated for each alternative. The LWR fuel cycle was judged the most developed in all areas, followed by HWRs because of the experience with the SRP reactors. Although the fuel fabrication for FFTF/CRBRP is available, reprocessing and waste management have not been demonstrated. The approximate amount of reprocessed fuel is given below for several reactors, based on Ref. 1 .

\section{RRY Reprocessing}

Reactor Type ____ Amount

\begin{tabular}{lr} 
LWR & $25 \mathrm{t}$ \\
LMFBR & $20 \mathrm{t}$ \\
CANDU & $115 \mathrm{t}$ \\
CANDU (Pu recycle) & $60 \mathrm{t}$ \\
\hline
\end{tabular}

\section{E. Summary}

Existing LWRs and new HWRs have approximately the same potential for defense production activities. However, a detailed cost-benefit analysis is needed to quantify this potential. The FFTF/CRBRP alternative is also very attractive because of already invested federal funding and their locations at government-owned sites.
Without further analysis, the FFTF/CRBRP option appears to be the most cost-effective alternative. but has a higher risk in product assurance.

\section{v. CONCLUSIONS}

To assure the required production levels of plutonium and tritium beyond 1992, more fuel cycle options are now available than in the 1940 s and 1950s. In addition to the proposed RPRs being considered, the only practicable solutions for plutonium and tritium production are HWRs (such as CANDU and CANDU-type reac. tors) or existing commercial power reactors at a govern. ment site.

Each option is viable only with accompanying separa tion facilities for its specific fuel and target assemblies. The real potential of these alternatives depends on the availability of BNFP for reprocessing and on the re source economics of the associated fuel cycle. If the defense fuel cycle were to include reprocessing of spent fuel from commercial reactors, a constant source of plutonium would be possible. Tritium requirements. including target reprocessing. could then be met with dedicated nuclear facilities such as reactors or even accelerators. However, the traditional "Atoms for Peace" attitude toward commercial power reactors and other institutional reasons might preclude the use of existing commercial reactors.

Barring a change in the US approach to separation of civilian and defense fuel cycles, and without the use of existing commercial reactors at government sites, the most viable alternatives are CANDU-type HWRs at SRP site and the Three Mile Island reactors, with transportation of spent fuel and reprocessing capability at BNFP and SRP.

\section{A. Use of Existing Commercial Reactors}

Production of tritium, plutonium, or both. can be achieved in any existing commercial reactor with implementation of certain changes in the reactor core design. fuel mix. fuel management. or a combinatiun of all three, depending on production goals and optimization economics. This alternative becomes particularly operable if the reactor(s) are located in a governmentowned site or if they are idle for political reasons. Spent fuel could be transported to a reprocessing facility for separation of plutonium and/or tritium. BNFP and the 
tritium separation facility at SRP appear well suited for reprocessing.

The US government could buy or lease an existing commercial reactor for defense materials production. if provision could be made for separation of defense materials from spent fuel. The issue of whether each commercial reactor should be required to produce defense materials depends on the federal government assuming responsibility for reprocessing of all spent fuels. If the defense cycle includes reprocessing of civilian spent fuel, plutonium production would be assured, as outlined in the national fuel cycle discussed in Sec. II. To produce tritilim, either special target assemblies would be used in the commercial reactors or special dedicated nuclear facilities (reactors or accelerators) would be built to assure the required amounts. Serious consideration should be given to integrating the civilian fuel cycle with the defense fuel cycle and to assigning fuel fabrication and reprocessing responsibility to DOE.

\section{B. Use of Existing and Planned Government-Owned Facilities}

The most significant potential among those DOE facilities not now being used for defense material production involves the use of FFTF and CRBRP in production of plutonium and tritium. Core fuel designs and fuel management should be altered to optimize production. Fuel and target reprocessing might be done at Hanford Purex Plant and Idaho Chemical Processing Plant, respectively. However, if BNFP were available, its use, with target processing at SRP, might be more cost effective. A cost-benefit analysis is recommended for net results.
Training and naval reactors owned by DoD do not provide a rational alternative because of technical, programmatic. and cost-benefit reasons.

\section{Construction of HWRs}

Another significant alternative is to construct CANDU of CANDU-type HWRs at government sites. If a purchase from Canada is not possible becaus? of political and economic reasons, a pressurized $H W / R$ could be built by a US reactor manufacturer. By locating such a reactor at the SRP site, reprocessing could be done for fuel and target at BNFP and at SRP, respectively. More study is needed to assess the economics of plutonium and tritium production in such a system.

BNFP has potential for becoming a multiple purpose reprocessing plant for spent fuels from LWRs, LMFBRs. and HWRs. An engineering evaluation of its operability is recommended to resolve the present controversy about its design (see Appendix A).

\section{ACKNOWLEDGMENTS}

The large number of individuals consulted in the preparation of this study unfortunately precludes mentioning them by name. The outstanding cooperation of nuclear experts at Los Alamos National Laborarnry, Oak Ridge Operations Office, and Idaho National Engineering Laboratory (in particular, Yale D. Harker and Daniel E. Wessol for their referenced work) is greatly appreciated.

\section{APPENDIX A}

\section{NUCLEAR FUEL PROCESSING}

In an LWR fuel cycle with uranium and plutonium recycle, as shown in Fig. A-1, the sensitive facilities (that is, with high risk for safeguards) are the enrichment plant, the fuel reprocessing plant, and the recycle fuel fabrication plants. When LMFBRs operate in tandem with LWRs, these facilities remain the same.
Figure A-2 shows a fuel reprocessing facility where spent fuel is processed to separate uranium and plutonium as products. A block diagram of this facility is presented in detail in Fig. A-3, ${ }^{17}$ where various chemical and physical separations are followed by conversion of 
uranium to $\mathrm{UF}_{6}$ and plutoniuin to $\mathrm{PuO}_{2}$ products by the Purex process.

BNFP in South Carolina was built "to recover both uranium and plutonium from irradiated fuel elements which are discharged from light water moderated and cooled nuclear power reactors." 18 The plant can process annually $1500 \mathrm{t}$ of uranium in fresh fuel elements that had a fissile content of up to $5 \%{ }^{233} \mathrm{U}$ or the equivalent for plutonium fuels. BNFP can process irradiated nuclear pewer reactor fuel consisting of uranium oxide, or a mixture of plutonium oxide and uranium oxide, clad in stainless steel or zirconium alloys. Tables A-I-III privide a comparison of BNFP with other commercial repr,icessing facilities, outlining their similarities, difference , and major waste systems. ${ }^{9}$

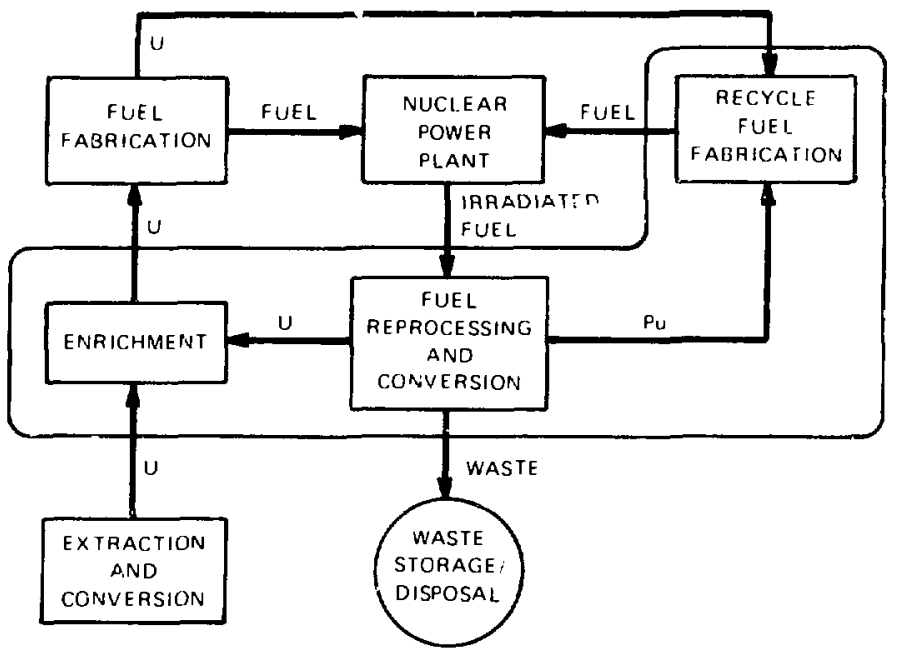

Fig. A-I.

Low-enrichment uranium-plutonium fuel cycle.

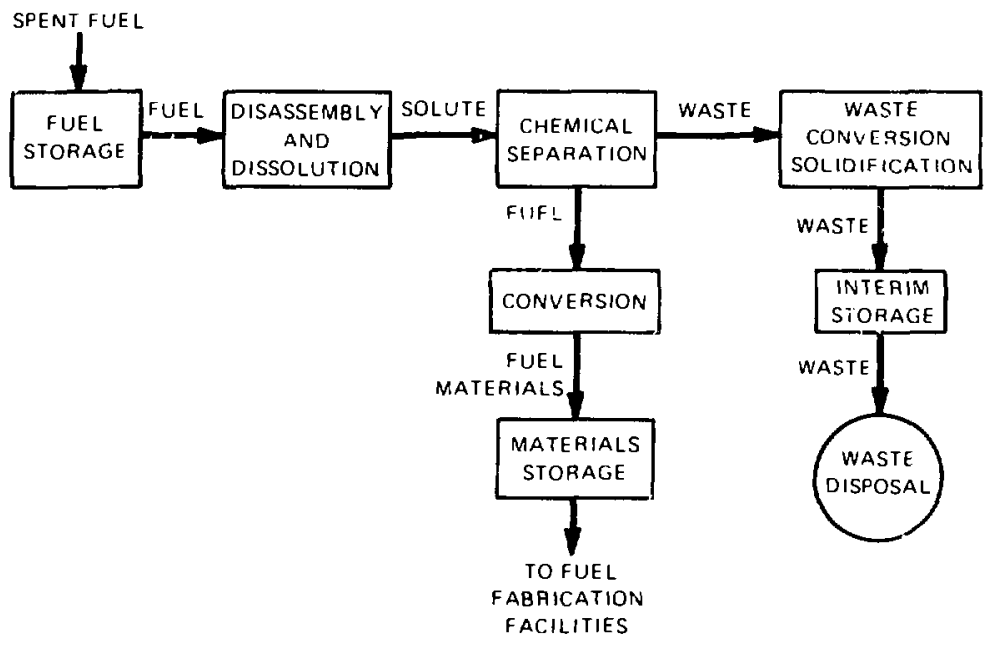

Fig. A-2.

A fuel reprocessing facility. 


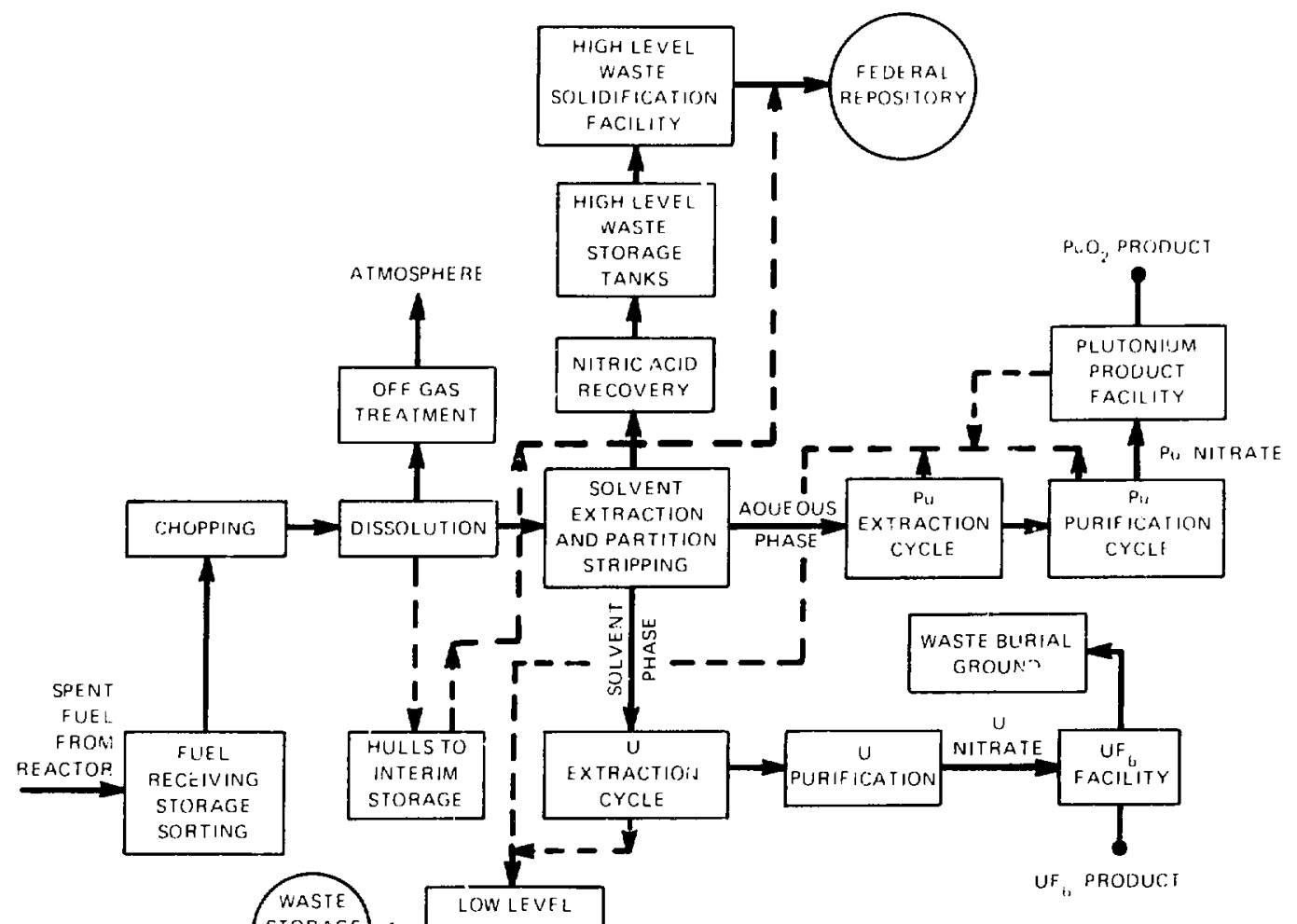

Fig. A-3.

Reprocessing by the Purex process.

TABLE A-I

\section{PRINCIPAL SIMILARITIES AMONG BNFP AND OTHER COMMERCIAL REPROCESSING FACILITIES}

\begin{tabular}{|c|c|c|c|}
\hline Item & BNFP & NFS & MFRP \\
\hline $\begin{array}{l}\text { Fuel unloading and } \\
\text { storage }\end{array}$ & Underwater & Underwater & Underwater \\
\hline Headend process & Chop-leach & Chop-leach & Chop-leach \\
\hline $\begin{array}{l}\text { Stored fuel } \\
\text { criticality safety }\end{array}$ & Spacing & Spacing & Spacing \\
\hline Fuel chopping & Mechanical shear & Mechanical shear & Mechanical shear \\
\hline $\begin{array}{l}\text { Fuel dissolution } \\
\text { material }\end{array}$ & Nitric acid & Nitric acid & Nitric acid \\
\hline $\begin{array}{l}\text { Fuel dissolution } \\
\text { technique }\end{array}$ & Semicontinuous & (No similarity) & Semicontinuous \\
\hline Fuel dissolution & Baskets in dissolvers & Baskets in dissolvers & (No similarity) \\
\hline Final exhaust & $\begin{array}{l}\text { Alternate contact with } \\
\text { sodium carbonate and } \\
\text { nitric acid solutions } \\
\text { Roughing and HEPA }\end{array}$ & $\begin{array}{l}\text { Alternate contact with } \\
\text { sodium carbonate and } \\
\text { nitric acid solutions } \\
\text { Roughing and HEPA }\end{array}$ & $\begin{array}{l}\text { Alternate contact with } \\
\text { sodium carbonate and } \\
\text { nitric acid solutions } \\
\text { (No similarity) }\end{array}$ \\
\hline
\end{tabular}


TABLE A-II

\section{PRINCIPAL DIFFERENCES AMONG BNFP AND OTHER COMMERCIAL REPROCESSING PLANTS}

\begin{tabular}{|c|c|c|c|}
\hline Item & BNFP & NFS & MFRP \\
\hline Location & South Carolina & New York & Illinois \\
\hline Design capacity & $s \mathrm{tU} / \mathrm{d}$ & $1 \mathrm{tU} / \mathrm{d}$ & $1 \mathrm{tU} / \mathrm{d}$ \\
\hline Shearing & $\begin{array}{l}\text { Entire fuel elements } \\
\text { including end fittings }\end{array}$ & $\begin{array}{l}\text { End fitting removed } \\
\text { before shearing }\end{array}$ & $\begin{array}{l}\text { Pins removed from } \\
\text { fuel elements before } \\
\text { shearing pins only }\end{array}$ \\
\hline $\begin{array}{l}\text { Criticality control } \\
\text { in dissolver }\end{array}$ & Soluble poison & Geometric limitations & Geometric limitations \\
\hline $\begin{array}{l}\text { Fuel dissolution } \\
\text { technique }\end{array}$ & Semicontinuous & Batch & Semicontinuous \\
\hline $\begin{array}{l}\text { Fuel dissolution } \\
\text { equipment }\end{array}$ & Baskets in dissolvers & Baskets in dissolvers & $\begin{array}{l}\text { Vibratory leacher } \\
\text { tray }\end{array}$ \\
\hline HA contactor & Centrifugal contactor & Pulse column & Pulse column \\
\hline $\begin{array}{l}\text { Partitioning } \\
\text { technique }\end{array}$ & Electropuise column & $\begin{array}{l}\text { Solvent extraction with } \\
\text { chemical valence } \\
\text { adjustment }\end{array}$ & Ion exchange \\
\hline $\begin{array}{l}\text { Interim high level } \\
\text { waste storage form }\end{array}$ & $\begin{array}{l}\text { Acidic solution } \\
\text { (1-5 molar) }\end{array}$ & Basic solution & Calcined solid \\
\hline $\begin{array}{l}\text { Iodine removal from } \\
\text { process off-gas }\end{array}$ & $\begin{array}{l}\text { Mercuric nitrate/ } \\
\text { iodine srubbers plus } \\
\text { iodine/silver zeolite } \\
\text { adsorption beds }\end{array}$ & Silver reactor & $\begin{array}{l}\text { Sodium hydroxide } \\
\text { scrubbers, heated } \\
\text { silver zeolite }\end{array}$ \\
\hline Process vent filters & Roughing and HEPA & FIEPA & Packed fiberglass filter \\
\hline Final exhaust filters & Roughing and HEPA & Roughing and HEPA & Sand filter \\
\hline Feed clarification & Centrifuge & None & None \\
\hline Tritium disposal & As vapor up stack & As water to creek & As vapor up stack \\
\hline Uranium product form & Nitr tte solution & Nitrate solution & Hexafluoride \\
\hline Liquid effluent & Noncontaminated & Contaminated & Noncontaminated \\
\hline
\end{tabular}


TABLE A-III

MAJOR WASTE STREAMS FOR FUEL REPROCESSING PLANTS ${ }^{a}$

\begin{tabular}{|c|c|c|c|c|}
\hline \multirow[b]{2}{*}{ Plant } & \multirow[b]{2}{*}{ Gaseous Effluents } & \multicolumn{2}{|c|}{ Liquid Wastes } & \multirow[b]{2}{*}{ Solid Wastes } \\
\hline & & High Level & Other than High Level & \\
\hline NFS & $\begin{array}{l}\text { To atmosphere by } \\
\text { iodine scrubber, } \\
\text { HEPA filters, } \\
61-\mathrm{m} \text { stack. }\end{array}$ & $\begin{array}{l}\text { Stored onsite as } \\
\text { neutralized } \\
\text { liquid in tanks } \\
\text { in vault. }\end{array}$ & $\begin{array}{l}\text { Controlled release to } \\
\text { creek. }\end{array}$ & $\begin{array}{l}\text { Stored onsite } \\
\text { in drums in } \\
\text { impervious } \\
\text { clay deposits. }\end{array}$ \\
\hline MFRP & $\begin{array}{l}\text { To atmosphere by } \\
\text { iodine scrubber, } \\
\text { sand filter, } \\
\text { 91-m stack. }\end{array}$ & $\begin{array}{l}\text { Converted to solid. } \\
\text { Stored onsite in } \\
\text { containers under } \\
\text { water in storage } \\
\text { basin.c }\end{array}$ & $\begin{array}{l}\text { Stored onsite in tanks } \\
\text { in vault as immobile } \\
\text { salt cake. }\end{array}$ & $\begin{array}{l}\text { Stored onsite } \\
\text { in underground } \\
\text { lined vault. }\end{array}$ \\
\hline BNFP & $\begin{array}{l}\text { To atmosphere by } \\
\text { iodine scrubber, } \\
\text { silver zeolite } \\
\text { adsorber, HEPA } \\
\text { filters, I00-m } \\
\text { stack. }\end{array}$ & $\begin{array}{l}\text { Stored onsite as } \\
\text { acidic liquid in } \\
\text { tanks in vault. }\end{array}$ & $\begin{array}{l}\text { Stored onsite in tanks } \\
\text { in vault. }\end{array}$ & $\begin{array}{l}\text { Stored onsite } \\
\text { in concrete or } \\
\text { steel drums. }\end{array}$ \\
\hline
\end{tabular}

\footnotetext{
${ }^{a}$ Information in this table has been complied from the safety analysis reports for these facilities. Only the NFS plant has act: ally generated waste to date.

${ }^{b}$ Plans were to add tanks for storage of high level radioactive liquids in acidic conditions for ultimate conversion to solids and transfer to a Federal storage facility.

${ }^{c}$ Before shipment to Federal storage facility.

'Plans for solidification of high level radioactive liquid wastes for transfer to Federal storage facility.
} 


\section{APPENDIX B}

\section{TRANSPORTATION IN NUCLEAR FUEL CYCLE}

Use of existing commercial reactors to produce defense materials (as discussed in Secs. II and III.A) would require transportation of spent fuel to reprocessing facilities. Several studies have been performed to identify radioactive material transportation requirements and transportation systems to meet these requirements for nuclear fuel cycles. ${ }^{19,20}$

The LWR fuel cycles under consideration inciude the once-through (Fig. B-1) and the uranium-plutonium recycle (Fig. B-2). Heavy-metal shipments are shown by double arrows and low level waste (LLW) shipments are

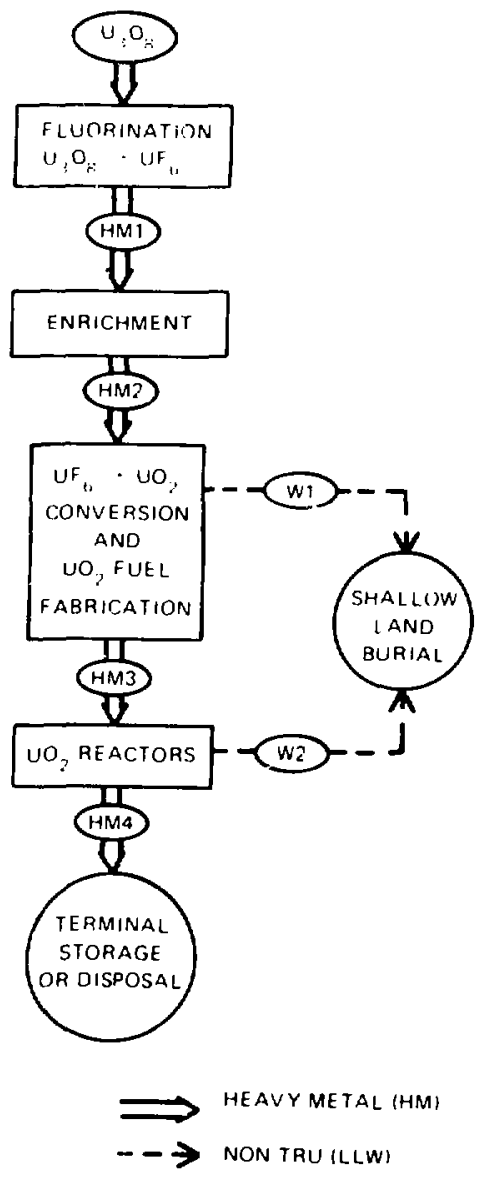

designated by either a single arrow (TRU waste) or a dashed arrow (non-TRU waste). Federal regulations regarding the transportation of radioactive ma'erials are contained in the code of Federal Regulations, Titles 10 and 49; an overview of the regulatory structure is given in Fig. B-3.

Reference 6 reported estimated transportation costs associated with LWR once-through and recycle fuel cycles for shipment of fuel, high level wastes (HLW) and LLW. Table B-I summarizes their estimates in 1979 dollars.
Fig. B-1.

Transportation in an LWR once-through fuel cycle. 


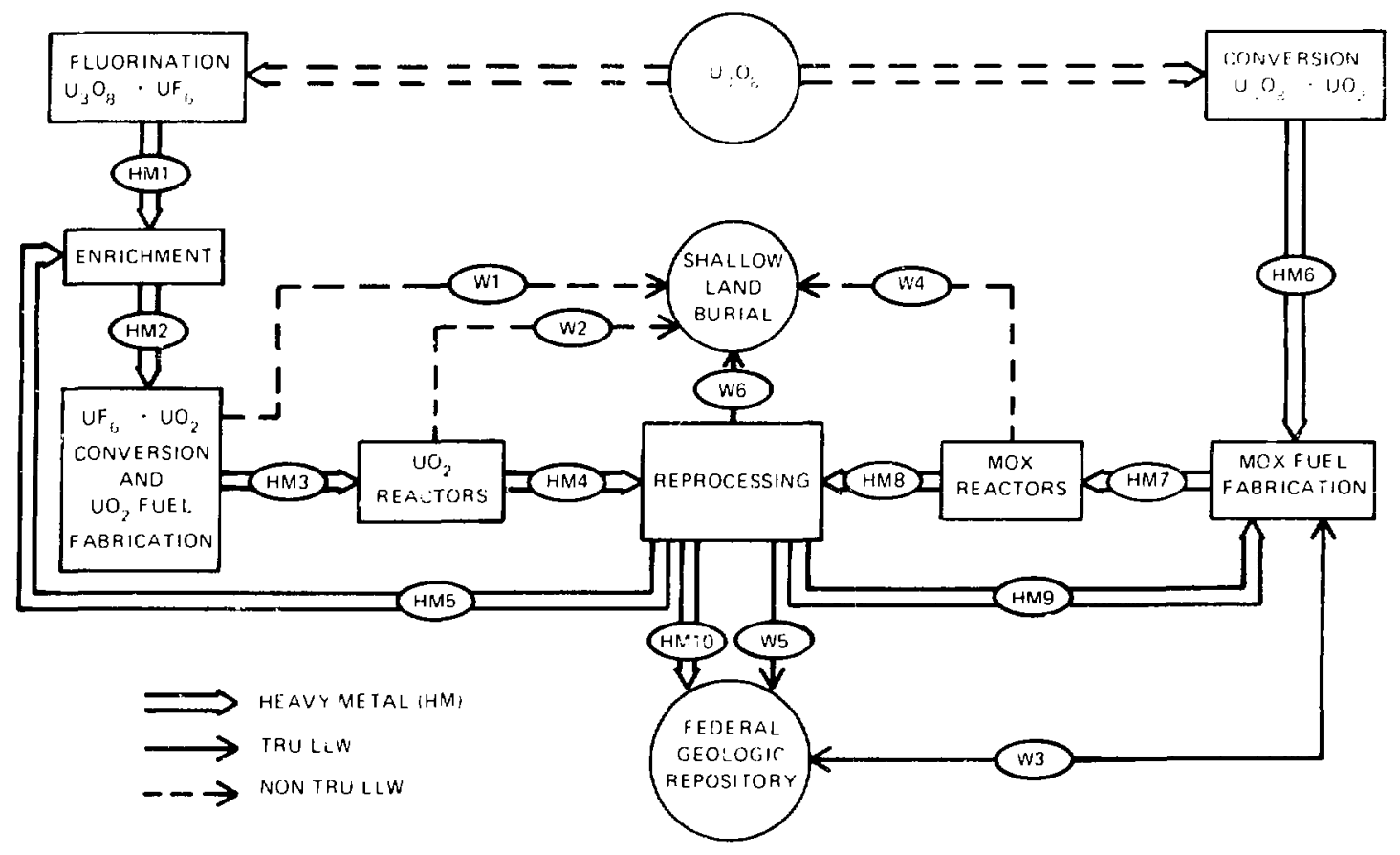

Fig. B.2.

Transportation in an $L W R$ fuel cycle with uranium-plutonium recycle.

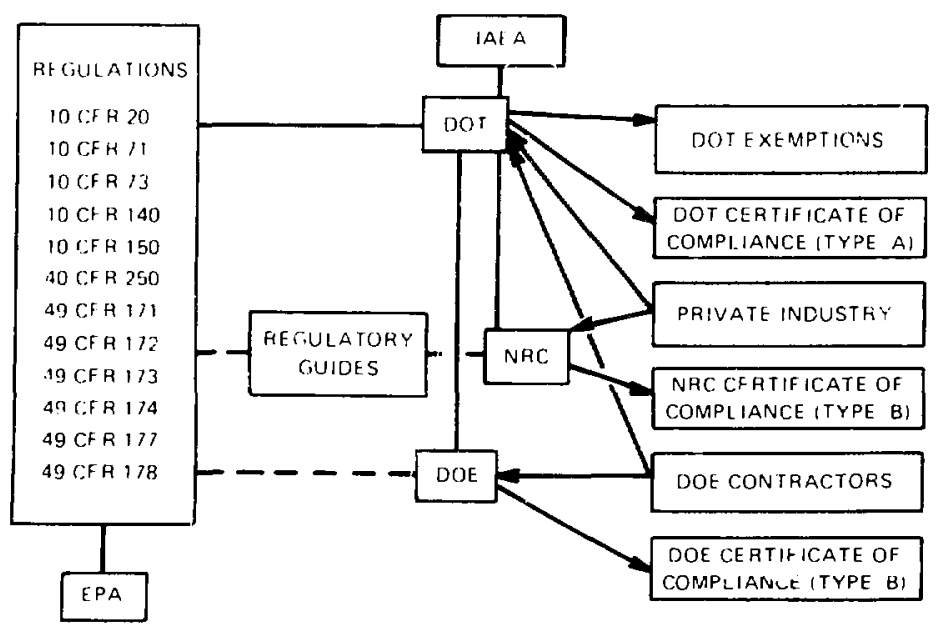

Fig. B-3.

Regulatory structure for ransportation of radioactive materials in the civilian fuel cycle. 
TABLE B-I

SUMMARY OF RADIOACTIVE MATERIAL TRANSPORTATION COSTS

FOR LIGHT-WATER REACTORS"

\begin{tabular}{|c|c|c|c|c|c|c|c|}
\hline \multirow{4}{*}{$\begin{array}{c}\text { Transportation } \\
\text { Segment }\end{array}$} & \multirow[b]{4}{*}{ Description } & \multicolumn{6}{|c|}{ Annual Transportation Cost, $\mathbf{5 0 0 0 ^ { b }}$} \\
\hline & & & & \multicolumn{4}{|c|}{ U/Pu Recycle } \\
\hline & & \multicolumn{2}{|c|}{ Once-Through } & \multicolumn{2}{|c|}{$\mathrm{UO}_{2}$-Fueled LWR } & \multicolumn{2}{|c|}{ MOX-Fueled LWR } \\
\hline & & Cost & \% of Total & Cost & \% of Total & Cost & $\%$ of Total \\
\hline HM 1 & Natural UF & $\$ 26$ & 5 & 520 & 3 & $\mathbf{s}$ & $\mathbf{0}$ \\
\hline HM2 & Enriched UF & 12 & 2 & 12 & 2 & $\mathbf{0}$ & 0 \\
\hline HM3 & $\mathrm{UO}_{2}$ fresh fuel & 26 & 5 & 26 & 4 & $\mathbf{0}$ & 0 \\
\hline HM4 & $\mathrm{UO}_{2}$ spent fuel & 252 & 52 & 282 & 44 & $\mathbf{0}$ & 0 \\
\hline HM5 & Recycle $\mathrm{UO}_{2}$ & $\mathbf{0}$ & 0 & 4 & 1 & $\mathbf{0}$ & 0 \\
\hline HM6 & Natural $\mathrm{UO}_{2}$ & $\mathbf{0}$ & $\mathbf{0}$ & $\mathbf{0}$ & $\mathbf{0}$ & 4 & 0.4 \\
\hline HM7 & MOX fresh fuel & $\mathbf{0}$ & $\mathbf{0}$ & 0 & 0 & 132 & 12 \\
\hline HM8 & MOX spent fuel & 0 & 0 & 0 & 0 & 554 & 52 \\
\hline HM9 & Recycle $\mathrm{PuO}_{2}$ & 0 & 0 & 0 & 0 & 84 & 8 \\
\hline \multirow{3}{*}{$\begin{array}{l}\text { HM10 } \\
\text { W1 }\end{array}$} & High level waste & 0 & 0 & 64 & 10 & 64 & 6 \\
\hline & $\mathrm{UO}_{2}$ fabrication & & & & & & \\
\hline & waste & 6 & 1 & 6 & 1 & 0 & $\mathbf{0}$ \\
\hline w2 & $\begin{array}{l}\mathrm{UO}_{2} \text { reactor } \\
\text { waste }\end{array}$ & 166 & 34 & 166 & 26 & 0 & 0 \\
\hline w3 & $\begin{array}{l}\text { MOX fabrication } \\
\text { waste }\end{array}$ & 0 & $\mathbf{0}$ & 0 & 0 & $\mathbf{0}$ & 1 \\
\hline w4 & $\begin{array}{l}\text { MOX reactor } \\
\text { waste }\end{array}$ & 0 & 0 & $\mathbf{0}$ & 0 & 166 & 15 \\
\hline \multirow[t]{2}{*}{ W5 } & $\begin{array}{l}\text { Reprocessing } \\
\text { clad waste }\end{array}$ & $\mathbf{0}$ & 0 & 26 & 4 & 26 & 2 \\
\hline & TRU waste & 0 & 0 & 2 & 0.3 & 2 & 0.2 \\
\hline W6 & $\begin{array}{l}\text { Reprocessing } \\
\text { non-TRU waste }\end{array}$ & 0 & 0 & 29 & 5 & 29 & 3 \\
\hline \multicolumn{2}{|c|}{ Total annual cost } & $\$ 490$ & & $\$ 640$ & & $\$ 1100$ & \\
\hline
\end{tabular}

"Results are normalized to $1000-\mathrm{MW}(\mathrm{e})$ reactor design power and assume a nominul $70 \%$ capacity factor.

'In 1979 dollars. 


\section{APPENDIX C}

\section{ACCELERATORS AND FUSION REACTORS}

High-energy particle accelerators and future fusion reactors could be used with fission systems to produce fissile materials. Such an accelerator breeder has been proposed as an RPR to produce plutonium and tritium (see Table I). In Appendix $\mathbf{C}$ accelerator tritium breeders, fusion-fission reactors, and pure fusion reactors are discussed.

\section{Accelerator Tritium Breeders}

Accelerators have been used for many years to produce particie beams with energies to thousands of $\mathrm{MeV}$. A moderately high energy device producing charged particles such as protons or deuterons has a potential to breed tritıum from a fertile as: :mbly containing lithium. This concept differs from the proposed electronuclear breeder in that it has no uranium or actinides in the system. The charged particles could be made to strike a target such as lead to produce a shower of neutrons, which would convert the fertile blanket surrounding the target to tritium (see Fig. C-1).

${ }^{6} \mathrm{Li}+{ }^{1} \mathrm{n} \rightarrow{ }^{4} \mathrm{He}+\mathrm{T}$.

The blanket material then would be processed to recover the tritium thus proviuced.

Such a system woulu use large amounts of electrical energy to run the accelerator and to produce kilogram quantities of iritium. If the cost of the accelerator and its operation is low enough that tritiun is produced at an acceptable price, an accelerator breeder might be realized in our future. For example, it is possible that the CRBRP-generated electric power (375 MW) couid run an accelerator to produce several kitograms of tritium (see Fig. C-2).

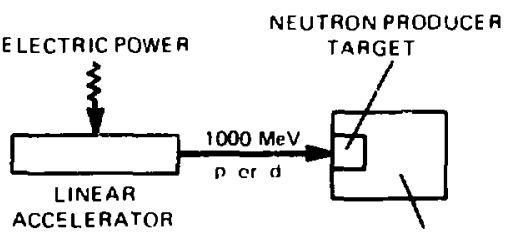

rig. C.1.

Accelerator tritium breader concept.

LI CONTAINING BLANKET

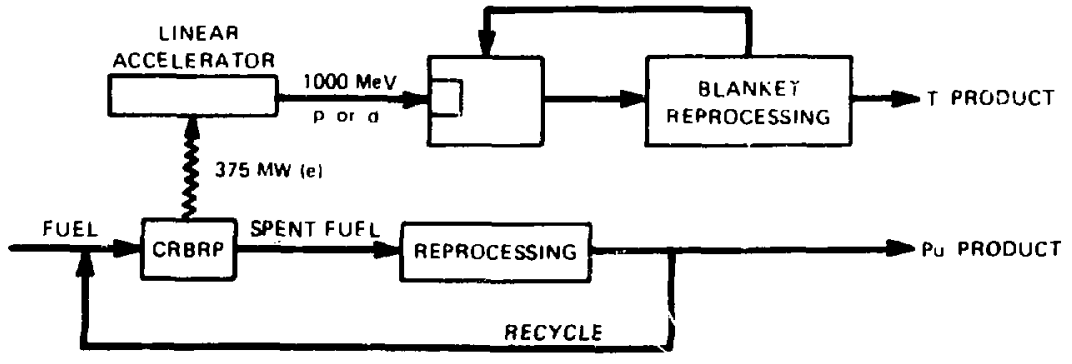

Fig, C-2.

Operation of CRBRP in tandem with a linear accelerator to produce plutonium and tritium. 


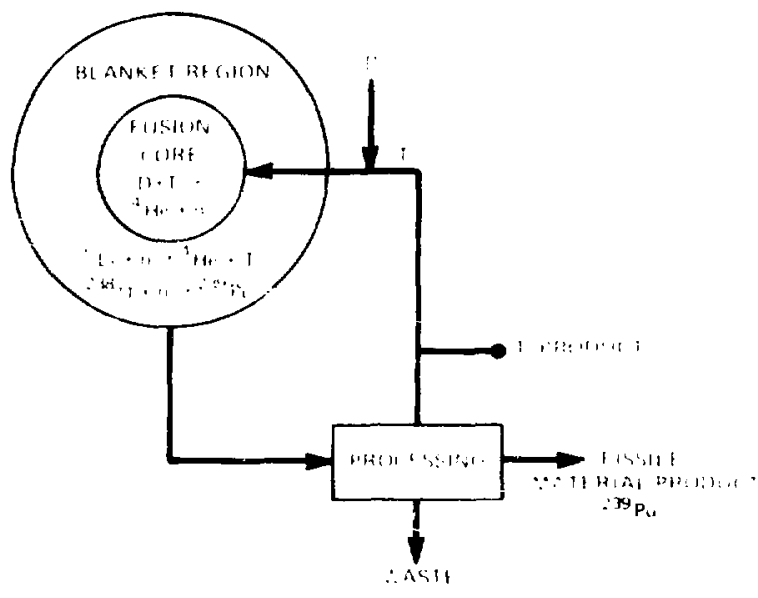

Fig. C. 3.

A fusion fission hybrid to produce plutonium and tritium.

\section{Fusion Reactors}

The present fusion reactor development involves the following reaction that produces $17.6 \mathrm{MeV}$ in the form of neutron and $\alpha$ particle energy.

$\mathrm{D}+\mathrm{T} \rightarrow{ }^{4} \mathrm{He}(3.5 \mathrm{MeV})+{ }^{1} \mathrm{a}(14.1 \mathrm{MeV})$.

Magnetic confinement and inertial confinement concepts are the two main lines of reactor development. As illustrated in Fig. C-3, the fusion-produced neutrons may be used to convert a fertile material. ${ }^{21 k}$, , to a fissile material. ${ }^{234} \mathrm{Pu}$. or to convert ${ }^{6} \mathrm{Li}$ to tritium. A pure fusion reactor would contain only lithium, in pure or compound form, in the blanket region to make the trit um needed as fuel for the fusion process. A fusionfission reactor would produce not only tritium to be self sufficient but also fissile maicrials such as ${ }^{210} \mathrm{Pu}_{\mathrm{u}}$."

\section{REFERENCES}

1. Anthony V. Nero, Jr., A Guidebock to Nuclear Reactors (University of California Press. Berkeley. California. 1979).

-Because fusion-fission reaciors have a less demanding developmental level. the goal of the USSR fusion development program is to build fusion-fission reactors that are expected to be available before pure fusion reactors.
2. L. Charles Hebel. Cumpiler. "Report to the American Physical Society by the Study Group on Nucle. ar Fuel Cycles and Waste Management," Rev. Mod. Phys. 50. No. I. Part II (January 1978).

3. Amory B. Lovins. "Nuclear Weapons and Power Reactor Plutonium." Nature 283. No. 5750. 817.82 .3 (1980).

4. N. Glyden and L. W. Holm, "Risks of Nuclear Explo:ves Production in Secret." US Friergy Research and Development Administration translation ERDA-tr-45 (1974).

5. ¿. G. Croff, Compiler, "Revised UraniumPluionium CYic PWR and BWR Modeis for the ORIGEN Computer Code." Oak Ridge National Laboratory report ORNL/TM-6051 (September 1978).

6. S. A. Dupree and L. C. O'Malley, "Economics of Radioactive Material Transportation in th: Light Water Reactor Nuclear Fuel Cycle." Sandia Naiional Laboratories encrgy report SAND80-0035 (Octoher 1980).

7. Victor Gilinsky, "Nuclear Reactors and Nuclear Bombs," Chem. Eng. News 59, No. 3, 87-90 (1981). 
8. "AIF Sees Doubling of Nuclear's Role in U.S.," The Energy Daily (October 4, 1980).

9. GESMO. General Enviranmental Statement on the Use of Recycle Plutonium in Mixed Oxide Fuel in LWR's, Vols. 1-4 (US Atomic Energy Commission Directorate of Licensing. Washington. D.C., August 1974).

in $n$ niel Martin. Three Mile Island: Prologue or cilogue? (Ballinger Publishing Company, Camoridge, Massachusettes, 1980).

11. Yale D. Harker and Daniel E. Wessol, "Preliminary Study of Demonstration. Test, Research, and Training Reactors for Special Nuclear Materials Production," EG\&.G informal report EGG-PHYS.5387 (March 1981).

12. N. L. Shapiro and J. F. Jesick. "Concepri:al Design of a Large Henvy-Waser Reactor for U.S. Siting." Combustion Engineering. Inc. repurt CEND-379, Vols. 1-4 (September !979).

13. "P1-kering Generating Station. A Tritium Removal System," Ontario Hydro Nuclear Materials Man agement Department, special monthly report (No vember 1980!.

14. "Licensing Assessment of CANDU Pressurized Heavy Water Reactor (Preliminary Safety Information Document)." United Engineers and Construc. tors. Inc. report UEC-ERDA 770630. Vols. 1-2 (June 1977).
15. C. E. Till, E. M. John, Y. I. Chang. and J. B. VanErp. "A Survey of Considerations Involved in Introducing CANDU Reactors into the United States," Argonne National Laboratory rtoort ANL-76-132 (January 1977).

16. P. R. Kasten., Compiier, "Assessment of Thorium Fuel Cycle in Power Peactors." Oak Ridge National Labcratory report ORNL/TM 5565 (January 1977).

17. "Final Environmental Statemeni. Light Wattr Breeder Reactor Program. Commercial Application of LWBR Technology," Vols 1.5. US Energy Re scarch and Divelopnient Administration report ERDA 1541 (june 1976).

18. "Safety Evaluation by the Division of Materials Licensing in the Matter of Allied-Gulf Nuclear Services Barnwell Nuclear Fuel Plant." US Atomic Energy Commission Docket-50-332 (September 1970).

19. "Transportation of Radioactive Wastes from Nuclear Fuel Cycles." International Nuclear Fuel Cycle Evaluation report INFCE/DEP/WG.7/8. Vienna. Austria (1979).

20. R. F. Rhoads. "An Overview of Transportation in the Nuclear Fuel Cycle." Rattelle Pacific Northwest Laboratories report BNW!.2066 (May 1977). 